\title{
Polysaccharides with Antitumor Effect in Breast Cancer: A Systematic Review of Non-Clinical Studies
}

\author{
Claudia Rita Corso ${ }^{1,2,+} \oplus^{\infty}$, Natalia Mulinari Turin de Oliveira ${ }^{1,2,+}$, Leonardo Moura Cordeiro ${ }^{1,2}$, \\ Karien Sauruk da Silva ${ }^{1,2}$, Suzany Hellen da Silva Soczek ${ }^{1,2}$, Virgilio Frota Rossato ${ }^{1,2} \mathbb{D}$, Elizabeth Soares Fernandes ${ }^{1,2} \mathbb{D}$ \\ and Daniele Maria-Ferreira ${ }^{1,2, * \mathbb{D}}$ \\ 1 Instituto de Pesquisa Pelé Pequeno Príncipe, Faculdades Pequeno Príncipe, Curitiba 80250-060, PR, Brazil; \\ claudia_rcorso@hotmail.com (C.R.C.); natimulinari@gmail.com (N.M.T.d.O.); \\ leonardocmoura911@gmail.com (L.M.C.); Kariensauruk@outlook.com (K.S.d.S.); \\ suzanyhellen@gmail.com (S.H.d.S.S.); virgiliofrota@gmail.com (V.F.R.); \\ elizabeth.fernandes@pelepequenoprincipe.org.br (E.S.F.) \\ 2 Programa de Pós-graduação em Biotecnologia Aplicada à Saúde da Criança e do Adolescente, Faculdades \\ Pequeno Príncipe, Curitiba 80230-020, PR, Brazil \\ * Correspondence: daniele.ferreira@pelepequenoprincipe.org.br or danielemariaferreira@gmail.com; \\ Tel.: +55-41-33101035 \\ + These authors contributed equally to this work.
}

check for updates

Citation: Corso, C.R.; Mulinari Turin de Oliveira, N.; Moura Cordeiro, L.; Sauruk da Silva, K.; da Silva Soczek, S.H.; Frota Rossato, V.; Fernandes, E.S.; Maria-Ferreira, D.

Polysaccharides with Antitumor Effect in Breast Cancer: A Systematic Review of Non-Clinical Studies. Nutrients 2021, 13, 2008. https:// doi.org/10.3390/nu13062008

Academic Editor: Kyung-Chul Choi

Received: 30 April 2021

Accepted: 5 June 2021

Published: 10 June 2021

Publisher's Note: MDPI stays neutral with regard to jurisdictional claims in published maps and institutional affiliations.

Copyright: (c) 2021 by the authors. Licensee MDPI, Basel, Switzerland. This article is an open access article distributed under the terms and conditions of the Creative Commons Attribution (CC BY) license (https:/ / creativecommons.org/licenses/by/ $4.0 /)$.
Abstract: Purpose: To review the effects of polysaccharides and their proposed mechanisms of action in breast cancer experimental models. Data sources, selection, and extraction: Articles were selected by using PubMed, ScienceDirect, Scopus, and Medline, assessed from 1 May 2019 to 1 July 2020. The systematic review was registered in the International Prospective Register of Systematic Reviews (Prospero) under the number CRD42020169103. Results: Most of the studies explore algae polysaccharides (43.2\%), followed by mushrooms (13.5\%), plants (13.5\%), fruits (10.8\%), fungus $(2.7 \%)$, bacteria, $(2.7 \%)$, and sea animals $(2.7 \%)$. A total of $8.1 \%$ investigated only in vitro models, $62.1 \%$ evaluated only in vivo models, and $29.7 \%$ evaluated in vitro and in vivo models. The mechanism of action involves apoptosis, inhibition of cellular proliferation, angiogenesis, and antimetastatic effects through multiple pathways. Conclusions: Findings included here support further investigations on the anti-tumor effect of polysaccharides. Some polysaccharides, such as fucoidan and $\beta$-glucans, deserve detailed and structured studies aiming at translational research on breast tumors, since they are already used in the clinical practice of other proposals of human health.

Keywords: polysaccharides; breast cancer; cancer treatment; nonclinical studies; natural source

\section{Introduction}

The recent advances in research and especially the better access to high-quality care associated with early diagnosis and medical treatment by specialized multidisciplinary teams has improved the survival and quality of life for breast cancer patients [1]. However, breast cancer still represents a significant health problem and is the most common malignancy affecting women around the world, despite being a highly curable disease when detected early [2,3]. Breast cancer incidence differs worldwide and takes into consideration risk factors, availability, and access to mammography for early disease diagnosis. Its incidence is higher in regions with high income (i.e., Australia, New Zealand, North America, and Northern and Western Europe), whereas the lowest incidence is found in low-income regions (i.e., Eastern Asia and middle Africa) [4,5]. In high-income countries, breast cancer is diagnosed at an early stage, often leading to a good prognosis and effective treatment, while in low-income countries, breast cancer is diagnosed later and is consequently associated with higher mortality rates [6].

The exact mechanism by which breast cancer initiates is unknown. However, it is established that the disease is characterized by a heterogeneous molecular expression with 
different clinical presentations in relation to histology, prognosis, and responsiveness to treatment. The disease is classified in hormonal breast cancer (the estrogenic receptor (ER) and/or progesterone receptor (PR) positive), human epidermal growth factor receptor 2 (HER2) positive, or triple-negative breast cancer (TNBC). Fundamentally, current treatment protocols have evolved to take this heterogeneity into consideration due to their predictive and prognostic implications [7].

Currently, the management of breast cancer is multidisciplinary. Non-metastatic breast cancer treatment goals include eradicating tumors from the breast and regional lymph nodes together with the prevention of metastatic recurrence with radiation therapy. Systematic therapy may be preoperative (neoadjuvant), postoperative (adjuvant), or both, and it includes a variety of treatment strategies based on the clinical pathological features of each case [8].

The systemic therapies include chemotherapy, endocrine therapy for hormone receptorpositive disease, anti-HER2 therapy for HER2-positive cases, as well as the incorporation of bone stabilizing agents, and recently, immunotherapy [9]. Differently, metastatic breast cancer therapy focuses on symptom palliation, improving or maintaining the quality of a patient's life, as the tumor remains incurable in nearly all affected patients [10].

Despite the great achievements in breast cancer treatment, drug resistance has been observed and continues to be one of the major causes of relapses and death [11]. In this context, many studies have pointed out that natural compounds present a range of biological properties and represent promising options for the discovery of new drugs. In fact, natural products exhibit anti-carcinogenic activity and can target several pathways involved in breast cancer (i.e., cellular proliferation, differentiation, apoptosis, angiogenesis, and metastasis) [12].

Among these products, polysaccharides have attracted attention because of their activity in different types of cancer [13]. Possible mechanisms demonstrated through in vivo and in vitro studies involve cytotoxicity, inhibition of tumor cell growth, apoptosis induction, and immune stimulation [14-20].

However, despite all the information available in the literature, a systematic review of non-clinical studies referring to the biological activities of polysaccharides in breast cancer is still not present. As information regarding clinical studies is scarce, these studies were not included in this systematic review. Therefore, this review focuses on the effects of polysaccharides from all sources that were studied in the last ten years and their proposed mechanisms of action in breast cancer experimental models. This study aims to provide clear and organized information that can be used as a base for further investigations.

\section{Methods}

This systematic review was carried out following the Preferred Reporting Items for Systematic Reviews and Meta-Analyses (PRISMA) guidelines [21], and its protocol was registered on the International Prospective Register of Systematic Reviews (Prospero) under the number CRD42020169103.

\subsection{Search Question}

PICOS (Participants, Intervention, Comparison, and Outcome) criteria were used to answer the following question: Does polysaccharide treatment have an antitumor effect on non-clinical breast cancer models? (Table 1).

\subsection{Search Strategy and Study Selection}

The search was performed in PubMed, Science Direct, Scopus, and Medline during May 2020 and was updated in June 2020. The search terms considered in this review included "polysaccharides" and "breast cancer" or "breast tumor" or "mammary cancer" or "mammary tumor" and were firstly evaluated in abstracts by two authors (C.R.C. and N.M.T.d.O.). The search strategy was adapted for each database when necessary. Duplicated records were removed by using the Mendeley software. The full-text appraisal was 
independently assessed by three authors (C.R.C., N.M.T.d.O. and L.C.M.). Discrepancies in any phases were resolved by the senior author (D.M.-F.).

Table 1. Description of the PICO (Participants, Intervention, Comparison, and Outcome) criteria used in the present systematic review.

\begin{tabular}{|c|c|}
\hline CRITERIA & DESCRIPTION \\
\hline PARTICIPANTS & $\begin{array}{l}\text { Non-clinical studies referring to the biological activities of } \\
\text { extracts or isolated polysaccharides in breast cancer } \\
\text { models (e.g., female murine models of breast cancer and } \\
\text { breast cancer cells) }\end{array}$ \\
\hline INTERVENTION & Extracts or isolated polysaccharides treatment \\
\hline COMPARISON(S) & $\begin{array}{c}\text { Comparison control groups (which were not treated with } \\
\text { polysaccharide) }\end{array}$ \\
\hline OUTCOMES (S) & $\begin{array}{c}\text { Changes in parameters related to the model of breast } \\
\text { cancer studied }\end{array}$ \\
\hline
\end{tabular}

\subsection{Inclusion and Exclusion Criteria}

The search was focused on original non-clinical studies referring to the biological activities of extracts or isolated polysaccharides (e.g., from plants, algae, and fungus) in breast cancer models (e.g., female murine models of breast cancer and breast cancer cells) and was limited to a period of publication (2010-2019) and to articles published in English. Studies in rodent experimental models (rats and mice) of breast cancer with or without metastasis and all breast cancer cell lines were included. Additionally, studies of ex vivo samples (e.g., blood and tumor tissue) of breast tumor models (human or murine) were considered. Only those with doses or concentrations of polysaccharide (isolated or in the form of extracts) below $3000 \mathrm{mg} / \mathrm{kg} / \mathrm{mL}$, and with primary (e.g., in vitro: cell viability or proliferation assay; in vivo: tumor weight, tumor volume) and secondary (e.g., biochemical and molecular assays) outcomes were eligible for inclusion.

Articles published in journals with no impact factor, as well as reviews, clinical trials, conferences, book chapters, and studies performed before 2010 were not eligible. Studies with animals with co-morbidities, males, other species rather than rats and mice, and in silico models were not included. Additionally, studies of polysaccharides bound to other compounds (e.g., peptides, antibody, nanoparticles) or studies on adjuvant treatment to chemotherapies were not included in this study.

\subsection{Data Extraction}

Data extraction was performed by four authors (C.R.C., N.M.T.d.O., L.C.M. and K.S.d.S.), and D.M.-F. was consulted to resolve disagreements. The following data were considered:

- Study design: number of experimental groups compared with the vehicle control group.

- Non-clinical models: for in vivo studies: female murine (mice or rats), adult animals (6 weeks of age) with breast cancer, such as xenograft model (e.g., MCF-7, MDA-MB231 cells) and syngeneic model (e.g., Ehrlich and Walker-256) at any weight body; for in vitro studies: any type of breast cancer cell line.

- Intervention: dose/concentration, time of treatment/incubation, and route of administration when applicable. Type, source, molecular weight, and structure of the polysaccharide.

- Outcome: primary: growth of breast cancer cells; for in vitro: the amount of cell proliferation or viability or migration; for in vivo: tumor volume and/or tumor weight. Secondary: mechanism of action of polysaccharide through biochemical and molecular assay in samples (cells or tumor tissue). 


\subsection{Assessment of Risk of Bias}

The methodological quality of each study was assessed considering the risk of bias (RoB) using SYRCLE's RoB tool for animal studies [22]. The assessment of the risk of bias was performed by five authors (C.R.C., N.M.T.d.O., L.C.M., V.F.R. and S.H.d.S.S.), and D.M.-F. was consulted to resolve disagreements. The assessment included baseline characteristics, allocation concealment, random housing, blinding (performance), random outcome assessment, blinding (detection), incomplete outcome data, selective outcome reporting, sequence generation, and other sources of bias, including the use of statistical analysis, presence of a control group, and complete methodology. Each analysis had three possible judgments ("low risk", "high risk", or "unclear risk"). If the information was not clear, the assessment "no information" was selected. For in vitro studies, "no information" was considered as "not applicable" for allocation and random housing. Articles considered to have a high risk of bias in the other source of bias were considered to have overall high risk and were not included in the systematic review.

\section{Results}

\subsection{Study Selection}

A total of 11,139 records were identified, including 4475 duplicated records and 6667 records screened by abstract and title. Of those, 6491 were excluded (they were not research or were short communications, or did not fit the criteria following title and abstract analysis). Following scrutiny, a total of 21 articles were included in the identification and screening phases through other references. Then, a total of 197 articles were assessed for eligibility. From this, a total of 160 articles were excluded due to the following reasons: duplicated articles $(n=2)$, articles that did not meet the identification criteria (reviews, articles published before 2010, and articles not in English, $n=36$ ), irrelevant population (did not evaluate breast cancer models or used male in vivo models, $n=8$ ), irrelevant exposure (did not evaluate polysaccharides per se, $n=80)$, and high risk of bias $(n=34)$. Finally, data analysis was performed in 37 studies. The flowchart of studies selected in the systematic review can be seen in Figure 1.

\subsection{Risk of Bias Assessment}

Of note, $94.1 \%$ of the in vivo studies reported efforts of experimental group randomization, but no one specifically described the randomization procedure. Only one study mentioned that it performed blinding protocol analysis. It is important to point out that $76.3 \%$ of the studies were of in vitro protocols. Thus, the random allocation and blinding of participants and blinding outcome assessment domains were considered "not applicable". Overall, around $47.2 \%$ of the studies had no statistical analysis, had no control groups, or presented incomplete methodology (considered as other sources of bias) and were therefore eliminated from this systematic review. The risk of bias assessment is summarized in Figure 2 .

\subsection{Data Extraction}

Sixteen manuscripts (43.2\%) analyzed polysaccharides derived from algae, $5(13.5 \%)$ from mushrooms, five (13.5\%) from plants, five (13.5\%) from fruits, four $(10.8 \%)$ from fungus, one (2.7\%) from bacteria, and one (2.7\%) from sea animals (Figure 3 ). All studies included in the systematic review are summarized in Table 2 [23-59]. From the 37 articles included in this systematic review, three (8.1\%) evaluated only in vivo models, $23(62.1 \%)$ evaluated only in vitro models, and $11(29.7 \%)$ evaluated both in vitro and in vivo models. The anti-tumor effects of each polysaccharide will now be discussed separately by their source of extraction. 


\section{Identification}

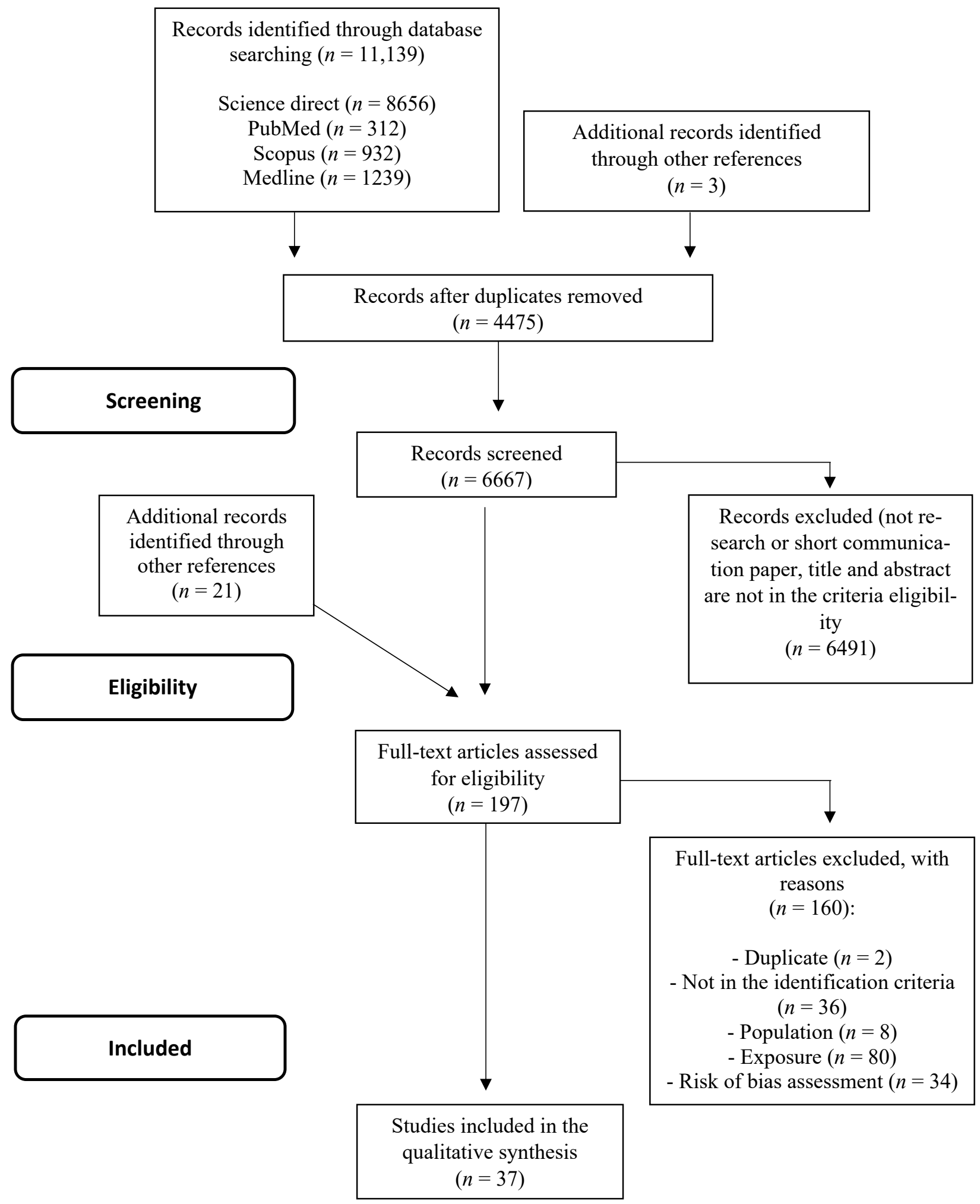

Figure 1. PRISMA Flowchart of the structured literature review. 
Random sequence generation Allocation concealment Blinding of participants and personnel

Blinding of outcome assessment Incomplete outcome data

Selective reporting Other sources of bias

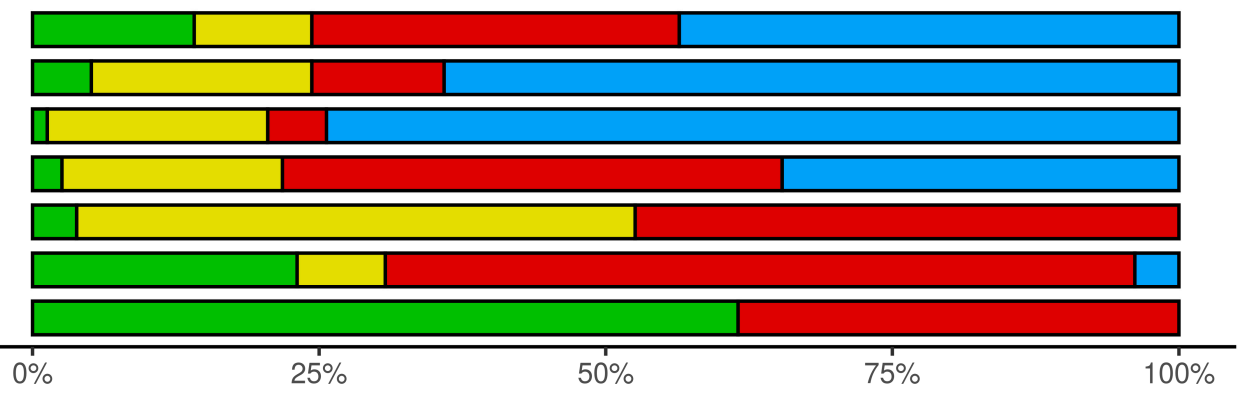

Low risk of bias

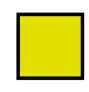

Some concerns

High risk of bias

No information

Figure 2. Risk of bias assessment. Evaluation of the methodological quality and assessment of the risk of bias using the SYRCLE's RoB tool for animal studies. The bars represent the percentage of articles found in each category. Other sources of bias: statistical analysis, presence of control group, or complete methodology. No information also means not applicable for in vitro studies.

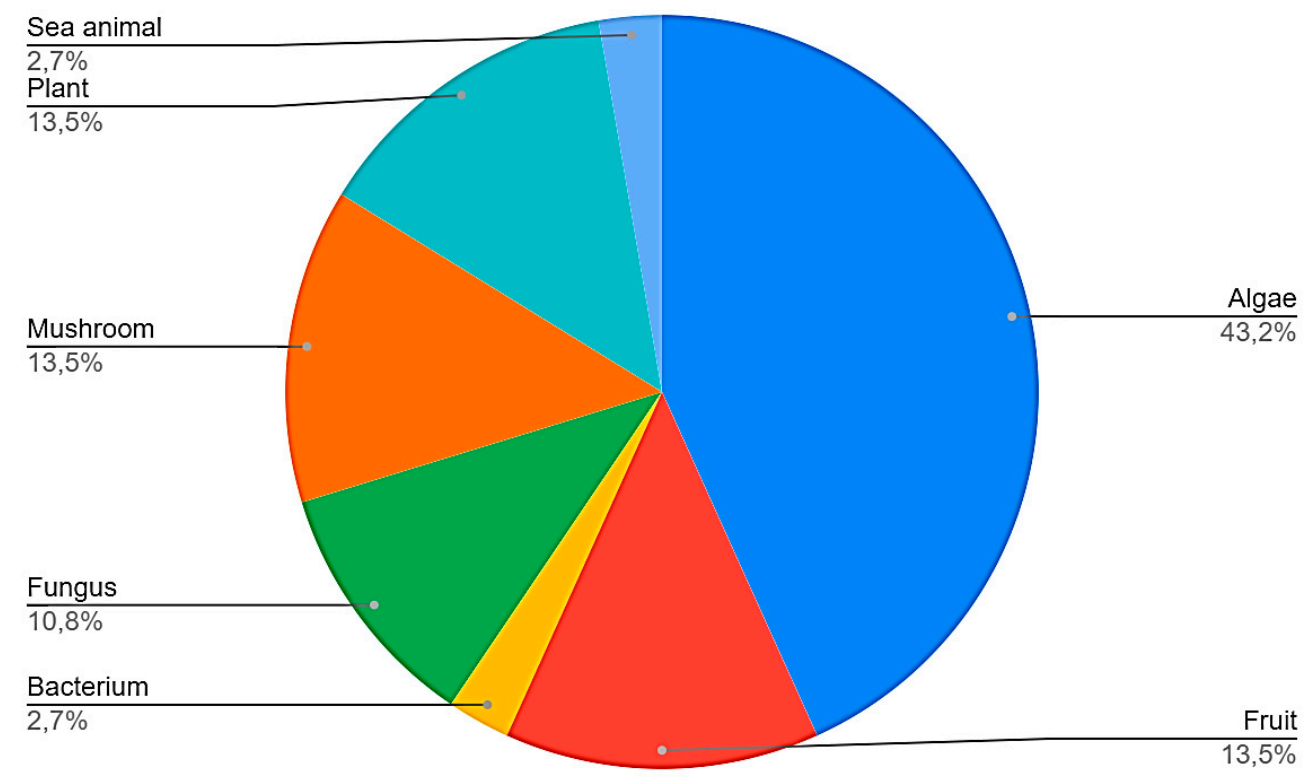

Figure 3. Sources of polysaccharides found in the studies selected in the systematic review.

\subsection{Sea Animals}

Only one report that extracted polysaccharides from sea animals was found. Lee et al. [23] investigated a starfish polysaccharide (PS) from Asterina pectinifera. By employing an in vitro model using MCF-7 cells, they found that PS reduced cyclooxygenase 2 (COX-2) mRNA and aromatase levels in a concentration-dependent manner $(10,20,40,80$, and $120 \mu \mathrm{g} / \mathrm{mL}$ for $24 \mathrm{~h}$ ). The expression of MMP-9 was decreased and mRNA expression of tissue inhibitor of matrix metalloproteinase (TIMP)-1, a MMP inhibitor, was increased mainly at 40, 80, and $120 \mu \mathrm{g} / \mathrm{mL}$. PS reversed phosphorylation of p38, ERK, and JNK [23]. 
Table 2. Mechanism of action of different polysaccharides.

\begin{tabular}{|c|c|c|c|c|c|c|c|}
\hline SOURCE & Species & Polysaccharide & In Vitro Model & In Vivo Model & $\begin{array}{l}\text { Concentration/ } \\
\text { Dose }\end{array}$ & $\begin{array}{l}\text { Mechanism of Action/ } \\
\text { Antitumor Effect }\end{array}$ & Reference \\
\hline SEA ANIMALS & $\begin{array}{l}\text { Asterina } \\
\text { pectinifera }\end{array}$ & Ps & MCF-7 & - & $\begin{array}{c}10,20,40 *, 80 * \\
120 * \mu \mathrm{g} / \mathrm{mL}\end{array}$ & $\begin{array}{l}\text { Inhibit metastasis through COX-2 and } \\
\text { MMP-9 via downregulation of MAPK } \\
\text { pathway }\end{array}$ & $\begin{array}{l}\text { Lin, Shi, and } \\
\text { Nam } \\
(2013)[23]\end{array}$ \\
\hline \multirow{9}{*}{ ALGAES } & \multirow{7}{*}{$\begin{array}{l}\text { Fucus } \\
\text { vesiculosus }\end{array}$} & \multirow{7}{*}{ Fucoidan } & $4 \mathrm{~T} 1$ & 4T1 (mice) & $\begin{array}{c}50 *, 100 * \text {, and } 200 * \mu \mathrm{g} / \mathrm{mL} \\
5 * \text { and } 10^{*} \mathrm{mg} / \mathrm{kg}\end{array}$ & $\begin{array}{l}\text { Apoptosis through mitochondrial } \\
\text { pathway, inhibit angiogenesis through } \\
\text { downregulation of VEGF and ERK } \\
\text { signaling and inhibit metastasis }\end{array}$ & $\begin{array}{l}\text { Xue et al. } \\
\text { (2012) [24] }\end{array}$ \\
\hline & & & $4 \mathrm{~T} 1$ & 4T1 (mice) & $\begin{array}{l}25^{*}, 50^{*}, 100 * \text {, and } \\
200 * \mu \mathrm{g} / \mathrm{mL} \\
5^{*} \text { and } 10^{*} \mathrm{mg} / \mathrm{kg}\end{array}$ & $\begin{array}{l}\text { Inhibit proliferation through } \\
\text { downregulation of cyclin } \mathrm{d} 1 \text { and } \\
\text { wnt } / \beta \text {-catenin signaling }\end{array}$ & $\begin{array}{l}\text { Xue et al. } \\
\text { (2013) [25] }\end{array}$ \\
\hline & & & $\begin{array}{c}4 \mathrm{~T} 1 \\
\text { MDA-MB-231 }\end{array}$ & 4T1 (mice) & $\begin{array}{l}60,90 *, 100 * \text {, and } \\
120 * \mu \mathrm{g} / \mathrm{mL} \\
0.25 * \mathrm{mg} / \mathrm{kg}\end{array}$ & $\begin{array}{l}\text { Inhibit metastasis through } \\
\text { tgfr/smad/snail, slug, twist and emt axes }\end{array}$ & $\begin{array}{l}\text { Hsu et al. } \\
(2013)[26]\end{array}$ \\
\hline & & & MDA-MB-231 & - & $10,50 *$, and $100 * \mu \mathrm{g} / \mathrm{mL}$ & Apoptosis through er stress & $\begin{array}{l}\text { Chen et al. } \\
\text { (2014) [27] }\end{array}$ \\
\hline & & & MDA-MB-231 & DMBA (rat) & $\begin{array}{c}6.25 *, 12.5 * \text {, and } \\
25^{*} \mu \mathrm{g} / \mathrm{mL} \\
200 * \text { and } 400 * \mathrm{mg} / \mathrm{kg}\end{array}$ & $\begin{array}{l}\text { Inhibit proliferation and induce apoptosis } \\
\text { through downregulation of } \\
\text { PI3K/AKT/gsk3 } \beta \text { pathway }\end{array}$ & $\begin{array}{l}\text { Xue et al. } \\
(2017 a)[28]\end{array}$ \\
\hline & & & - & DMBA (rats) & $200 *$ and $400 * \mathrm{mg} / \mathrm{kg}$ & $\begin{array}{l}\text { Immunosuppression of treg through } \\
\text { PD1/PDL1 pathway }\end{array}$ & $\begin{array}{l}\text { Xue et al. } \\
(2017 b)[29]\end{array}$ \\
\hline & & & $\begin{array}{l}\text { MCF-7 with ex vivo } \\
\text { sample (blood from } \\
\text { Sprague Dawley } \\
\text { Rats) }\end{array}$ & - & $200 *$ and $400 * \mathrm{mg} / \mathrm{kg}$ & $\begin{array}{c}\text { Inhibit proliferation, induce apoptosis, } \\
\text { and inhibit migration through } \\
\text { downregulation of MMP-9 and } \\
\text { upregulation of e-cadherin }\end{array}$ & $\begin{array}{l}\text { He et al. } \\
\text { (2019) [30] }\end{array}$ \\
\hline & $\begin{array}{l}\text { Laminaria } \\
\text { japonica }\end{array}$ & Fucoidan & MDA-MB-231 & - & $\begin{array}{c}0.125,0.25,0.5,1^{*}, \text { and } \\
2 * \mathrm{mg} / \mathrm{mL}\end{array}$ & $\begin{array}{c}\text { Inhibit angiogenesis and proliferation } \\
\text { through activation of MAPK and PI3K } \\
\text { followed by inhibition of ap- } 1 \text { and NF-KB } \\
\text { signaling }\end{array}$ & $\begin{array}{l}\text { Hsu et al. } \\
\text { (2020) [31] }\end{array}$ \\
\hline & $\begin{array}{l}\text { Cladosiphon } \\
\text { novae-caledoniae }\end{array}$ & $\begin{array}{l}\text { Fucoidan } \\
\text { (LMWF) }\end{array}$ & $\begin{array}{c}\text { MCF-7 } \\
\text { MDA-MB-231 }\end{array}$ & - & 82,410 , and $820 * \mu \mathrm{g} / \mathrm{mL}$ & $\begin{array}{l}\text { Apoptosis via mitochondria pathway } \\
\text { associated with ROS-dependent JNK } \\
\text { phosphorylation }\end{array}$ & $\begin{array}{l}\text { Zhang et al. } \\
\text { (2011) [32] }\end{array}$ \\
\hline
\end{tabular}


Table 2. Cont.

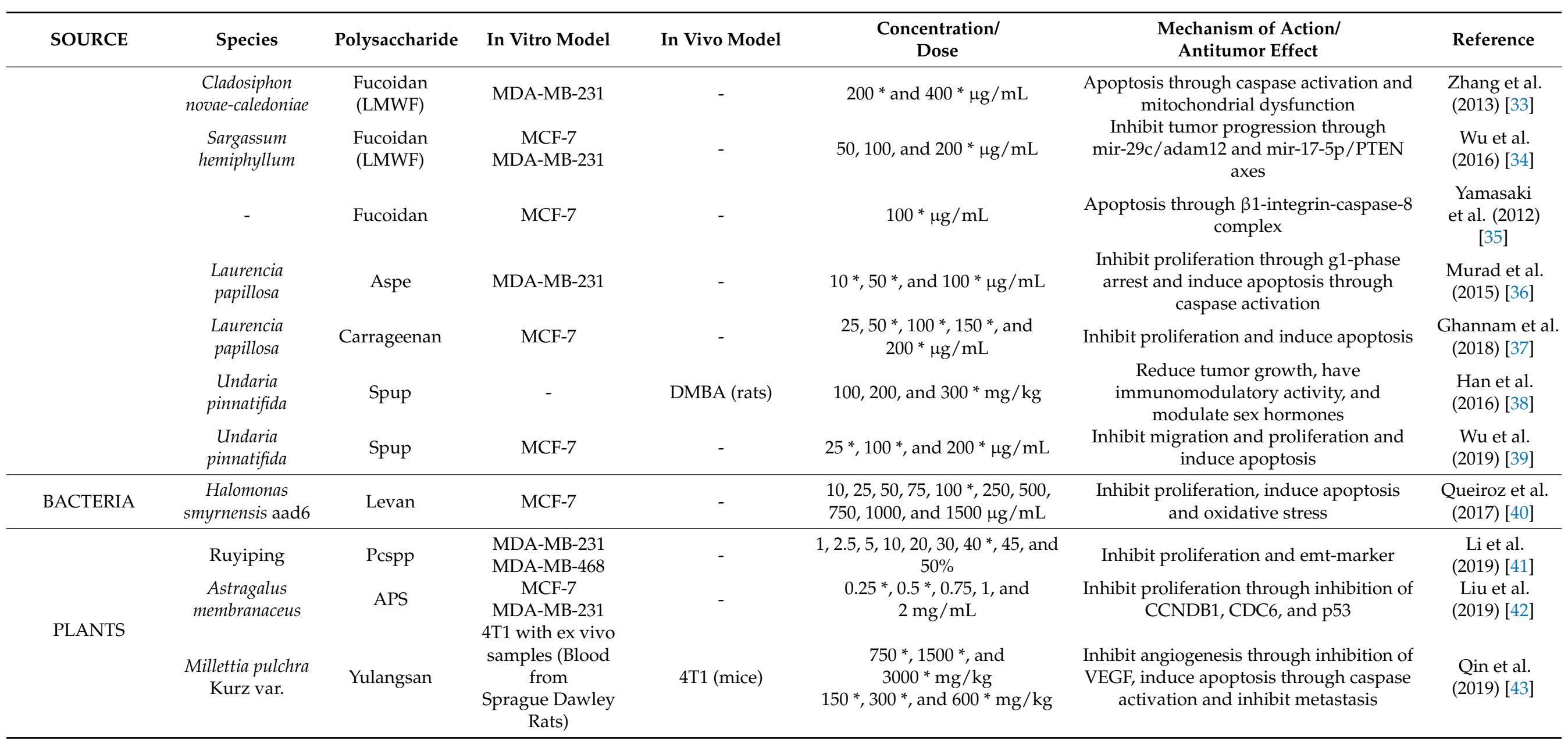


Table 2. Cont.

\begin{tabular}{|c|c|c|c|c|c|c|c|}
\hline SOURCE & Species & Polysaccharide & In Vitro Model & In Vivo Model & $\begin{array}{l}\text { Concentration/ } \\
\text { Dose }\end{array}$ & $\begin{array}{l}\text { Mechanism of Action/ } \\
\text { Antitumor Effect }\end{array}$ & Reference \\
\hline & $\begin{array}{l}\text { Sparganii } \\
\text { Rhizoma }\end{array}$ & SpaTA & $\begin{array}{c}\text { ZR-75-1 } \\
\text { MDA-MB-231 }\end{array}$ & - & $\begin{array}{c}76.4,152.8,305.6^{*} \text {, and } 611.2 * \\
\mathrm{mg} / \mathrm{L}\end{array}$ & Induce apoptosis through regulating ER $\alpha$ & $\begin{array}{l}\text { Wu, Sun, and } \\
\text { Wang } \\
\text { (2017) }[44]\end{array}$ \\
\hline & $\begin{array}{l}\text { Pyracantha } \\
\text { fortunean }\end{array}$ & Se-PFPs & MDA-MB-231 & $\begin{array}{l}\text { MDA-MB-231 } \\
\quad \text { (mice) }\end{array}$ & $\begin{array}{c}50,100 *, 200, \text { and } \\
400 * \mu \mathrm{g} / \mathrm{mL} \\
100 * \text { and } 400 *, \mathrm{mg} / \mathrm{kg}\end{array}$ & $\begin{array}{l}\text { Inhibit proliferation by arresting cells at } \\
\text { G2 phase via inhibiting } \\
\text { CDC25C-CyclinB1/CDC2 pathway and } \\
\text { induce apoptosis through p53-mediated } \\
\text { cytochrome c-caspase pathway }\end{array}$ & $\begin{array}{l}\text { Yuan et al. } \\
\text { (2016) [45] }\end{array}$ \\
\hline \multirow{5}{*}{ FRUITS } & $\begin{array}{c}\text { Lycium } \\
\text { barbarum } \\
\text { (wolfberry) }\end{array}$ & WFP & MCF-7 & - & $25,50,100 *$, and $200 * \mu \mathrm{g} / \mathrm{mL}$ & $\begin{array}{l}\text { Induce apoptosis and oxidative stress and } \\
\text { inhibit proliferation through the g0/g1 } \\
\text { cell cycle arrest }\end{array}$ & $\begin{array}{l}\text { He et al. } \\
(2012)[46]\end{array}$ \\
\hline & $\begin{array}{l}\text { Lycium } \\
\text { barbarum } \\
\text { (wolberry) } \\
\text { Citrus }\end{array}$ & LBP & MCF-7 & - & $\begin{array}{c}0.05,0.1,0.25,0.5^{*} \text {, and } \\
1 \mathrm{mg} / \mathrm{mL}\end{array}$ & $\begin{array}{l}\text { Inhibit angiogenesis through IGF-1 and } \\
\text { PI3K/HIF-1A/VEGF pathway }\end{array}$ & $\begin{array}{l}\text { Huang et al. } \\
\text { (2011) [47] }\end{array}$ \\
\hline & $\begin{array}{l}\text { sphaerocarpa } \\
\text { (hallabong } \\
\text { peels) }\end{array}$ & Hbe-ii & MDA-MB-231 & - & $\begin{array}{l}1.56,3.12,6.25,12.5,25 *, 50 \\
\text { and } 100 \mu \mathrm{g} / \mathrm{mL}\end{array}$ & $\begin{array}{l}\text { Inhibit metastasis through inhibition of } \\
\text { tube formation and MMP-9 }\end{array}$ & $\begin{array}{l}\text { Park et al. } \\
\text { (2016) [48] }\end{array}$ \\
\hline & Apple & Pectin & $4 \mathrm{~T} 1$ & 4T1 (mice) & $0.01,0.1,0.5$, and $1 * \% w / v$ & $\begin{array}{l}\text { Induce apoptosis and inhibit metastasis } \\
\text { through up-regulation of p53 }\end{array}$ & $\begin{array}{l}\text { Delphi et al. } \\
\text { (2016) [49] }\end{array}$ \\
\hline & $\begin{array}{l}\text { Capsicum } \\
\text { annuum }\end{array}$ & CAP & $\begin{array}{c}\text { MCF-7 } \\
\text { MDA-MB-231 } \\
\text { MDA-MB-436 }\end{array}$ & Ehrlich (mice) & $\begin{array}{c}0.025,0.05,0.1 *, 0.2 \\
0.4 \mathrm{mg} / \mathrm{mL} \\
50,100^{*} \text {, and } 150 \mathrm{mg} / \mathrm{kg}\end{array}$ & Inhibit proliferation and angiogenesis & $\begin{array}{l}\text { Adami et al. } \\
(2018)[50]\end{array}$ \\
\hline \multirow[b]{2}{*}{ FUNGUS } & S. Cerevisae & $\begin{array}{l}\text { B-(1-3)-d- } \\
\text { glucan }\end{array}$ & $\begin{array}{l}\text { MCF-7 } \\
\text { LCC9 }\end{array}$ & - & $\begin{array}{c}1,10 *, 50 *, 100,200,300 \text {, and } \\
400 \mu \mathrm{g} / \mathrm{mL}\end{array}$ & $\begin{array}{c}\text { Inhibit proliferation, induce apoptosis } \\
\text { and increase genes rassf1, IGFBP3, } \\
\text { CTNNB1, and ER } \beta\end{array}$ & $\begin{array}{l}\text { Jafaar et al. } \\
(2014)[51]\end{array}$ \\
\hline & $\begin{array}{l}\text { Botryosphaeria } \\
\text { rhodina } \\
\text { mamb-05 } \\
\text { Lasiodiplodia } \\
\text { theobromae } \\
\text { MMPI }\end{array}$ & $\begin{array}{l}(1-3)(1-6)-\beta-\mathrm{d}- \\
\text { glucan } \\
(1-6)-\beta-\mathrm{d}- \\
\text { glucan }\end{array}$ & MCF-7 & - & $\begin{array}{l}10,25,50,75,100 *, 250,750 \\
1000, \text { and } 1500 \mu \mathrm{g} / \mathrm{mL}\end{array}$ & $\begin{array}{l}\text { Inhibit proliferation, induce apoptosis, } \\
\text { necrosis, and oxidative stress mediated by } \\
\text { amp-activated protein-kinase and } \\
\text { forkhead transcription factor foxo3a }\end{array}$ & $\begin{array}{l}\text { Queiroz et al } \\
\text { (2015) [52] }\end{array}$ \\
\hline
\end{tabular}


Table 2. Cont.

\begin{tabular}{|c|c|c|c|c|c|c|c|}
\hline SOURCE & Species & Polysaccharide & In Vitro Model & In Vivo Model & $\begin{array}{l}\text { Concentration/ } \\
\text { Dose }\end{array}$ & $\begin{array}{l}\text { Mechanism of Action/ } \\
\text { Antitumor Effect }\end{array}$ & Reference \\
\hline & $\begin{array}{l}\text { Trichoderma } \\
\text { pseudokoningii }\end{array}$ & EPS & MCF-7 & - & $\begin{array}{c}0.10,0.25 *, 0.50 *, 0.75, \text { and } 1 * \\
\mathrm{mg} / \mathrm{mL}\end{array}$ & $\begin{array}{c}\text { Induce oxidative stress and apoptosis } \\
\text { through an intrinsic mitochondrial } \\
\text { pathway }\end{array}$ & $\begin{array}{l}\text { Wang et al. } \\
\text { (2015) [53] }\end{array}$ \\
\hline & $\begin{array}{l}\text { Aureobasidium } \\
\text { pullulan }\end{array}$ & $\begin{array}{l}\text { Pullulan } \\
\text { (PS) }\end{array}$ & - & 4T1 (mice) & $2.4 * \mathrm{mg} / \mathrm{kg}$ & Immunostimulant of macrophages m1 & $\begin{array}{l}\text { Xie et al. } \\
(2018)[54]\end{array}$ \\
\hline \multirow{5}{*}{ MUSHROOMS } & $\begin{array}{l}\text { Pholiota } \\
\text { dinghuensis bi } \\
\text { Trametes }\end{array}$ & PDP3 & MCF-7 & - & $13.5,28.2 *$, and $52.1 * \mu \mathrm{g} / \mathrm{mL}$ & $\begin{array}{l}\text { Inhibit proliferation and induce apoptosis } \\
\text { through p38/MAPK pathway }\end{array}$ & $\begin{array}{l}\text { Gan et al. } \\
\text { (2015) [55] }\end{array}$ \\
\hline & $\begin{array}{c}\text { robiniophila } \\
\text { murr } \\
\text { (hauier) }\end{array}$ & SP1 & MCF-7 & - & $100 *, 200 *$, and $400 * \mu \mathrm{g} / \mathrm{mL}$ & $\begin{array}{l}\text { Induce apoptosis through } \\
\text { downregulation bax and mtdh protein }\end{array}$ & $\begin{array}{l}\text { Luo et al. } \\
(2016)[56]\end{array}$ \\
\hline & $\begin{array}{l}\text { Mortierella } \\
\text { hepialid }\end{array}$ & MHP-1 & MCF-7 & $\begin{array}{l}\text { MDA-MB-231 } \\
\quad \text { (mice) }\end{array}$ & $\begin{array}{l}0.1 *, 1 * \text {, and } 10^{*} \mu \mathrm{m} \\
20,40, \text { and } 60 * \mathrm{mg} / \mathrm{kg}\end{array}$ & $\begin{array}{l}\text { Inhibit metastasis through inhibition of } \\
\text { TGF- } \beta \text { signaling }\end{array}$ & $\begin{array}{l}\text { Lin et al. } \\
(2016)[57]\end{array}$ \\
\hline & Lentinus edodes & $\begin{array}{l}\text { Lentinan } \\
{[\beta-(1-3)(1-6)-} \\
\text { d-glucan] }\end{array}$ & $\begin{array}{c}\text { MCF-7 } \\
\text { T47D } \\
\text { Mda-mb-231 } \\
\text { MAA-MB-468 }\end{array}$ & MCF-7 (mice) & $\begin{array}{c}12.5,25,50,100 *, 200 * \text {, and } \\
400 * \mu \mathrm{g} / \mathrm{mL} \\
1 * \mathrm{mg} / \mathrm{kg}\end{array}$ & $\begin{array}{l}\text { Inhibited tumor growth through } \\
\text { suppressing cell proliferation and } \\
\text { enhancing apoptosis via } \\
\text { PI3K/AKT/mTOR, NF-kB -, ERK-, ER } \alpha-\text {, } \\
\text { caspase-, and p53-dependent pathways }\end{array}$ & $\begin{array}{l}\mathrm{Xu}, \mathrm{Zou}, \text { and } \\
\mathrm{Xu}(2017)[58]\end{array}$ \\
\hline & Lentinus edodes & $\begin{array}{l}\text { Lentinan } \\
{[\beta-(1-3)(1-6)-} \\
\text { d-glucan] }\end{array}$ & MCF-7 & MCF-7 (mice) & $\begin{array}{c}15.6,31.3,62.5,125,250 *, 500 * \\
\text { and } 1000 * \mu \mathrm{g} / \mathrm{mL} \\
5^{*}, 10^{*} \text {, and } 20^{*} \mathrm{mg} / \mathrm{kg}\end{array}$ & $\begin{array}{l}\text { Induce autophagy through LC3 } \\
\text { conversion and apoptosis through } \\
\text { caspase-7-mediated mitochondrial } \\
\text { pathway }\end{array}$ & $\begin{array}{l}\text { Li et al. } \\
\text { (2018) [59] }\end{array}$ \\
\hline
\end{tabular}

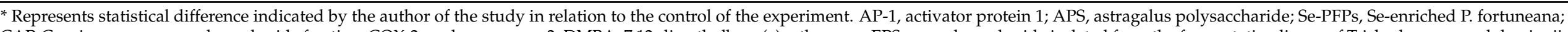

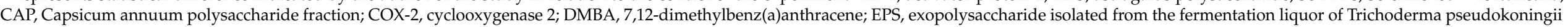

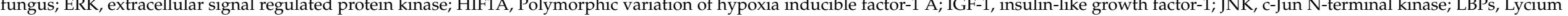

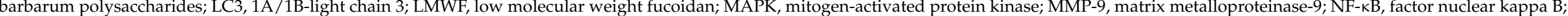

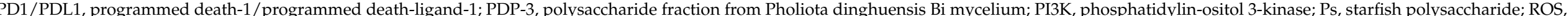
reactive oxygen species; TGF- $\beta$, transforming growth factor beta; VEGF, vascular endothelial growth factor; WFPs, wolfberry-derived polysaccharides 


\subsection{Algaes}

From 16 articles, 12 investigated the sulphated polysaccharide fucoidan. Four articles analyzed sulfated polysaccharides from Laurencia papillosa and Undaria pinnatifida. Three studies with fucoidan were further included in the data analysis after the search term "fucoidan" was used in the databases. Most of the studies with fucoidan (7) were derived from the algae Fucus vesiculosus, whereas two were from Cladosiphon novae-caledoniae Kylin, one was from Sargassum hemiphyllum, one was from Laminaria japonica and one study did not mention the source of the polysaccharide. Most of the studies with the fucoidan from Fucus vesiculosus (5) investigated in vivo models. Mammary carcinogenesis was induced in rats by using 7,12-dimethylbenz(a)anthracene (DMBA) in two studies, and $4 \mathrm{~T} 1$ mouse mammary cell linage (a model for stage IV of breast cancer) was used in three studies.

Xue et al. [24], conducted a study to investigate the antitumor effect of the crude fucoidan from F. vesiculosus, purchased from Sigma-Aldrich Corporation (St. Louis, MO, USA; MW: 20.000-200.000 kDa) on breast cancer bearing mice and in 4T1 mammary cells. In $4 \mathrm{~T} 1$ cells, fucoidan inhibited cell proliferation in a time-dependent manner, at the concentration of 50,100 , and $200 \mu \mathrm{g} / \mathrm{mL}$, for up to $72 \mathrm{~h}$ of incubation. Its antitumor effect was associated to a decreased expression of Bcl-2 and Bcl-2 to Bax ratio. The expression of survivin and phosphorylated extracellular signal regulated protein kinases (ERKs), which is required for angiogenesis, was also diminished [24]. A releasing of cytochrome c from the mitochondria into the cytosol and an increased cleaved caspase- 3 protein, after fucoidan treatment, were observed. Ten days after tumor inoculation, fucoidan (5 or $10 \mathrm{mg} / \mathrm{kg}$, intraperitoneally, every 2 days, for 10 days) reduced tumor growth and tumor weight. Similarly, a reduction in the number of vessels and vascular endothelial growth factor (VEGF) levels, as well as of apoptosis, was observed in tumor tissue sections [24]. As 4T1 cells have progressively spread metastases to the draining lymph nodes and other organs and are remarkably similar to those of human mammary cancer [60], the authors also investigated the potential of fucoidan in inhibiting metastasis. In fact, both fucoidan treatments (5 and $10 \mathrm{mg} / \mathrm{kg}$ ) reduced the number of lung metastases. As VEGF can promote tumor cell metastasis, the suppression of VEGF by fucoidan treatment in vivo is likely to be correlated with the antimetastatic effect [24].

To further investigate the mechanisms of fucoidan in protecting against breast cancer, the same group later showed that this molecule is able to inhibit cell growth and increase cell death. Indeed, induction of G1 cell cycle arrest in 4T1 cells was observed. Fucoidan also reduced $\beta$-catenin expression and $\mathrm{T}$ cell factor/lymphoid-enhancing factor reporter activity and downregulated the expression of apoptosis downstream target genes (c-myc, cyclin D1, and survivin) [25]. Similarly, Hsu et al. [26] found inhibition of cell viability in both $4 \mathrm{~T} 1$ and MDA-MB-231 cells $(60-120 \mu \mathrm{g} / \mathrm{mL}$ for 24 and $48 \mathrm{~h})$. Fucoidan treatment inhibited tumor growth and lung metastasis after 36 days in the $4 \mathrm{~T} 1$ in vivo model [26]. However, the authors did not give clear information on the dose and route of administration of the compound. Based on the observed antimetastatic effect of fucoidan, the authors investigated epithelial-mesenchymal transition (EMT) markers in 4T1 and MDA-MB-231 cells. Whilst E-cadherin expression was increased, N-cadherin was found to be diminished in these cells. The expression of the transcriptional repressors Snail, Slug, and Twist (EMT, epithelial to mesenchymal transition-related transcriptional repressors), was also reduced.

Indeed, fucoidan $(100 \mu \mathrm{g} / \mathrm{mL})$ presented anti-migratory and anti-invasive effects when incubated with $4 \mathrm{~T} 1$ and MDA-MB-231 cells, supporting its antimetastatic actions. These were associated with a rapid $(1 \mathrm{~h})$ and sustained $(24 \mathrm{~h})$ reduction of the transforming growth factor (TGFR) levels, Smad2/3 phosphorylation, and Smad4 expression. The evidence indicates that fucoidan has the potential to inhibit metastasis through regulation of a ubiquitin-dependent degradation pathway that affects the TGFR/Smad/Snail, Slug, Twist, and EMT axes [26].

Chen et al. [27], investigated whether endoplasmic reticulum stress (ER stress) is involved in fucoidan-induced cell apoptosis in the highly invasive and metastatic MDA-MB231 cells. Fucoidan incubation (50 and $100 \mathrm{ug} / \mathrm{mL}$ ) reduced the levels of GRP78, a protein 
responsible for the inhibition of cell apoptosis and the acceleration of ER-associated protein degradation [61]. The same study also showed that fucoidan increases the phosphorylation of calcium/calmodulin-dependent protein kinase 2 (CaMK2) and enhances Bax and caspase 12 levels. Furthermore, fucoidan inhibited the expression of X-box binding protein 1 (XBP1), as a result of decreased inositol-requiring enzyme 1 (IRE1) and eukaryotic translation initiation factor 2A (eIF2A) phosphorylation, and C/EBP homologous protein (CHOP) upregulation - a cascade activated via ER stress [62]. Of note, the phosphorylation of eIF2a results in the downregulation of global protein synthesis and in apoptosis through ER stress [63]. Overall, these data indicate that CHOP participates in fucoidan-induced DNA damage and suggest that this compound is able to modulate ER stress in breast cancer cells [27].

Later, Xue et al. [28] investigated the possible involvement of the phosphoinositide 3-kinase/protein kinase B/glycogen synthase kinase 3 beta (PI3K/PKB/GSK3b) pathway in the in vitro and in vivo actions of fucoidan [28]. Fucoidan treatment either in vivo (in DMBA-induced mammary cancer in rats, at 200 and $400 \mathrm{mg} / \mathrm{kg}$, by oral route, for 16 weeks) or in vitro (in MDA-MB-231 cells, at $6.25-25 \mathrm{mg} / \mathrm{mL}$ ) decreased the levels of p-PI3K, p-AKT, and p-GSK-3b (Ser9). The levels of $\beta$-catenin were also diminished [25]. Another suggested mechanism for fucoidan is the downregulation of $\beta$-catenin through the PI3K/AKT signaling pathway, which can regulate the phosphorylation of GSK3 $\beta$, or by directly affecting $\beta$-catenin [28].

Interestingly, in rats with DMBA-induced mammary cancer, fucoidan (200 and $400 \mathrm{mg} / \mathrm{kg}$, p.o., 4 months of treatment) also presented an immunomodulatory effect through the programmed death-1/programmed death-ligand-1 (PD1/PDL1) pathway. It was found that higher numbers of blood natural killer and CD4 and CD8 T cells, as well as the serum levels of interleukin (IL)-6, IL-12p40, and interferon (IFN)- $\gamma$, were elevated in rats treated with fucoidan. On the other hand, the percentage of Foxp $3^{+}$regulatory $\mathrm{T}$ cells and the levels of IL-10 and TGF- $\beta$ were lower. A reduction of Foxp $3^{+}$was also found in the tumor tissue, together with a reduction of PDL-1, PIK3, and p-AKT and augmented INF- $\gamma$ levels. These results suggest the immunomodulatory effect of fucoidan in DMBA-induced tumors is mediated by a PD1/PDL1/PI3K-AKT axis [29].

He et al. [30] evaluated the effects of the serum collected from healthy rats administered with fucoidan (MW: $675.5 \mathrm{kDa}, 200$ and $400 \mathrm{mg} / \mathrm{kg}$, by oral route, for 3 days) on the growth of MCF-7 cells. The serum significantly suppressed MCF-7 cell proliferation, migration, and invasion, whilst enhancing apoptosis [30]. These effects were associated with up-regulation of E-cadherin and downregulation of matrix metalloproteinase-9 (MMP-9). In addition, the study also suggested that cell invasion and migration were possibly inhibited via the decreased epithelial-mesenchymal transition (EMT) process [30]. More recently, Hsu et al. [31], investigated the effects of the fucoidan isolated from the algae Laminaria japonica ( $34 \%$ of ester sulfate, MW: $80 \mathrm{kDa}$ ) in MDA-MB-231 cells. By using concentrations of $0,0.125,0.25,0.5,1$, and $2 \mathrm{mg} / \mathrm{mL}$ ( 24 and $48 \mathrm{~h}$ of incubation), the authors found inhibition of the cell viability. The concentration of $2 \mathrm{mg} / \mathrm{mL}$ inhibited cell migration and invasion, suggesting that fucoidan inhibits tumor aggressiveness without inducing cell death. This effect was correlated with the downregulation of ERK, PI3K/AKT, mitogenactivated protein kinase (MAPK), c-Jun N-terminal kinase (JNK), mammalian target of rapamycin (mTOR), activator protein 1 (AP-1), and nuclear factor-kappa B (NF-kB) pathways. In addition, the antiangiogenic activity of fucoidan was confirmed in MDA-MB-231 cells through the reduction of VEGFA, IGF-I, MMP-2, and MMP-9 levels, basic fibroblast growth factor (bFGF), and the blockade of the adhesion and extravasation of tumor tissue to vascular endothelial cells. Fucoidan was also capable of inhibiting micro metastasis when MDA-MB-231-GFP cells were injected into the perivitelline cavity of zebrafish. Together, this set of data suggests that Laminaria japonica fucoidan has a potent antitumor effect by inhibiting metastasis and angiogenesis in triple-negative breast cancer cells [31].

Similarly, Zhang et al. [32], investigated the effect of a low molecular weight fucoidan (LMWF) (MW: $0.5 \mathrm{kDa}$ ) extracted from the brown algae Cladosiphon novae-caledoniae Kylin 
in breast cancer cells. This LMWF induced the apoptosis of MCF-7 and MDA-MB-231 cells when tested at the concentration of $820 \mathrm{ug} / \mathrm{mL}$, an effect that was found to be timedependent. The authors also demonstrated that LMWF-induced apoptosis of MCF-7 cells was caspase-independent and involved mitochondrial dysfunction, with alterations of $\mathrm{Ca}^{2+}$ homeostasis and reduction of the mitochondrial membrane potential, and the subsequent induction of cytochrome $c$ release, in addition to a decreased expression of antiapoptotic Bcl-2 family proteins [32]. The activation of this mitochondrial apoptotic pathway was associated with reactive oxygen species (ROS)-dependent JNK phosphorylation. Although most of the mechanisms of action were observed for LMWF in MDA-MB-231 cells, they were found to be associated with caspase activation [33].

Another LMWF (MW: 0.5-0.8 kDa) from brown seaweed Sargassum hemiphyllum also exhibits antiproliferative, anticlonogenic, and anti-migratory effects in breast cancer cells (MCF-7 and MDA-MB-231 cells). In addition, the LMWF from brown seaweed when incubated for $48 \mathrm{~h}$ at $200 \mu \mathrm{g} / \mathrm{mL}$ caused up-regulation of miR-29c miRNA and downregulation of miR-17-5p miRNA expressions in MDA-MB-231 cells. The up-regulation of miR-29c was independent of the downregulation of miR-17-5p, associated with decreased levels of ADAM12 and TGFB, resulting in EMT and metastasis inhibition. On the other hand, the downregulation of miR-17-5p was associated with increased levels of PTEN and downregulation of PI3K and AKT phosphorylation and consequently inhibition of cancer cell survival. These findings indicate that the LMWF from the brown seaweed Sargassum hemiphyllum, inhibits breast cancer progression by regulating miR-29c/ADAM12 and miR-17-5p/PTEN axes [34].

Furthermore, another study found that the incubation of fucoidan $(100 \mu \mathrm{g} / \mathrm{mL}$ for $48 \mathrm{~h}$ ) silences $\beta 1$-integrin gene expression and inhibits apoptosis in MCF-7 cells. Caspase 8 activation was also described. It suggests that $\beta 1$-integrin plays an important role in the interaction between fucoidan and the cell surface. This interaction was indispensable for caspase 8 activation and apoptotic death of MCF-7 cells. Although the results are interesting, the study lacked detailed information on the source and molecular weight of fucoidan, impairing its full comparison with the above-mentioned studies [35].

Four additional studies were found. Two from the red algae Laurencia papillosa and 2 from brown algae Undaria pinnatifida. Murad et al. [36], demonstrated the antiproliferative effect of $\mathrm{L}$-Carrageenan in MDA-MB-231 cells, which was correlated with apoptosis through an extrinsic pathway [36]. It was later shown that the lowest tested concentration $(10 \mu \mathrm{g} / \mathrm{mL})$ of a sulfated polysaccharide (namely ASPE) from Laurencia papillos induced G1-phase arrest, which was accompanied by up-regulation of Cip1/p21 and Kip1/p27 and downregulation of cyclin D, cyclin E transcripts, and their related inhibitors Cdk2, Cdk4, and Cdk6 [64]. When incubated at a high concentration $(50 \mu \mathrm{g} / \mathrm{mL})$, ASPE triggered apoptosis in MDA-MB-231 cells through increased caspase-3 and Bax expression and decreased levels of Bcl-2. In addition, over-generation of ROS was associated with ASPE-induced apoptosis. However, it was unclear on whether ASPE consists of $\iota$-carrageenan. Afterward, the effects of $\mathrm{k-}, \mathrm{l-}$, and $\lambda$-carrageenan, namely, LP-W1, LPW-2, and LPW-3, respectively, were investigated in MCF-7 cells [64]. Interestingly, only LPW-2 and LP-W3 (at 50, 100, 150, and $200 \mu \mathrm{M}$ for $24 \mathrm{~h}$ ) significantly inhibited cell proliferation, activated apoptotic genes such as PARP, caspase 3, and p53, and reduced Bcl-2 levels [37].

A polysaccharide from the brown algae Undaria pinnitafida was also studied. The authors conducted a study evaluating the effect of a sulphated polysaccharide from $U$. pinnitafida (SPUP) on DMBA-induced mammary cancer in rats. SPUP $(300 \mathrm{mg} / \mathrm{kg}$, by oral route, for 20 weeks) significantly inhibited tumor growth. The study described an immunomodulatory activity supported by the increased organ index (spleen and thymus). In addition, sex hormones such as estradiol, progesterone, prolactin, luteinizing hormone, and follicle-stimulating hormone, all imbalanced in DMBA vehicle-treated animals, were restored by SPUP administration. The result suggests that the anticancer mechanism of SPUP may be related to hormonal sex regulation. Later, the same group showed the antitumor effect of SPUP in MCF-7 cells. SPUP $(25,100$, and $200 \mu \mathrm{g} / \mathrm{mL})$ decreased cell 
viability in a concentration- and time-dependent manner. In addition, SPUP inhibited colony formation and migration and induced cell apoptosis [39].

\subsection{Bacteria}

Queiroz et al. [40] worked with MCF-7 cells and studied the effects of a levan $(2 \rightarrow 6)$ $\beta$-D-Fructan polysaccharide. Levan is a homopolymer of fructose units linked mainly by $\beta-(2 \rightarrow 6)$-D-fructofuranosyl bonds, with occasional $\beta-(2 \rightarrow 1)$-linked branched chains. It is produced in the extracellular matrix by a wide range of bacterial species [39]. The study isolated the levan polysaccharide from the gram-negative bacteria Halomonas smyrnensis AAD6T. This polysaccharide presented time (24 and $48 \mathrm{~h}$ )- and concentration $(0-1500 \mu \mathrm{g} / \mathrm{mL})$-dependent antiproliferative activity. Interestingly, levan caused apoptosis by increasing oxidative stress and inducing p53 (TP53 gene) and p27 (CDKN1B gene) gene expression $(100 \mu \mathrm{g} / \mathrm{mL}$ for $48 \mathrm{~h})$. The percentage of apoptotic cells in the sub-G1 phase was increased by this polysaccharide, whilst the percentage of those in G0-G1 phase was decreased. An increase in caspase $3 / 7$ activity was also observed. Therefore, levan polysaccharide exhibited an antiproliferative effect in MCF-7 cells that was mediated by an increase in apoptosis and oxidative stress [40].

\subsection{Plants}

There were five studies with plants, including two that employed in vitro and in vivo techniques and three studies that performed only in vitro experiments. Interestingly, the majority of the studies were from China, a well-known country for the study of herbal products.

Among the traditional Chinese medicine, Ruyiping has gained attention as a medicinal formula for preventing postoperative recurrence and metastasis of breast cancer patients. Ruyiping is composed of Pseudobulbus cremastra seu pleiones (Shancigu), Nidus vespae (Lufengfang), Curcuma zedoaria (ezhu), raw seeds of Coix lacryma-jobi L. var. mayuen (Roman.) Stapf (Shengyiyiren), and Akebiae fructus (Bayuezha). This herbal medicine (at $40 \%$ ) inhibits the growth and invasion of breast cancer by inducing cell cycle arrest and reducing MMP9 and EMT [41]. Ruyiping formula active components include Pseudobulbus cremastra seu pleiones polysaccharide (PCSPP) and curcumol. Indeed, PCSPP and curcumol were found to inhibit cell proliferation and EMT-related markers, suggesting that both components are responsible for Ruyiping effects. However, a limitation of the study is that no other component of Ruyiping formula was investigated [41].

Another Chinese herbal well explored is Astragalus membranaceus, which has been used for centuries as an immune stimulator, antiviral, antioxidant, and antitumor agent [65-70]. Astragalus polysaccharide (APS) was identified as one of the bioactive chemicals present in Astragalus membranaceus [66]. However, little is known of the mechanisms of action of APS in breast cancer. Thus, Liu at al. [42] employed an in silico method based on network pharmacology to screen APS mechanisms. Then, APS effects were investigated in MCF-7 and MDA-MB-231 cells. MCF-7 proliferation was significantly decreased after APS incubation $(0.25-2 \mathrm{mg} / \mathrm{mL}$; for $96 \mathrm{~h})$, whereas in MDA-MB-231 cells, only the highest concentrations $(0.75-2 \mathrm{mg} / \mathrm{mL})$ inhibited proliferation. Migration was also inhibited by ASP $(0.25-0.5 \mathrm{mg} / \mathrm{mL})$ in both tested cell lineages, and the expression of CCNB1 and CDC6 was decreased. p53 expression was increased in MDA-MB-231 cells. The results suggest a therapeutic potential for APS in breast cancer, possibly through modulation of CCNB1, CDC6, and p53 [42].

The roots of Yulangsan (Milleta pulchra Kurz var-laxior (Dunn) Z.Wei) are also famous herbal medicine in China with several biological properties, such as anti-inflammatory, anti-fibrosis, anti-viral, enhanced immunity, and antitumor activities [71-73]. Yulangsan polysaccharide (YLSPS) is the major effective extract from Yulangsan roots, and its antitumor effect has attracted considerable attention [43]. Therefore, Qin et al. [43] examined the antitumor effect of YLSPS on breast cancer cells. YLSPS was given to Sprague-Dawley rats at the doses of 750,1500, and $3000 \mathrm{mg} / \mathrm{kg}$ by oral route, twice a day for 7 days. The blood 
was collected, and the serum of the animals was cultured in RPMI medium to be further incubated with 4T1 cells as conditioned serum [74]. All tested concentrations of YLSPS decreased cell viability and increased apoptosis by increasing Bax and caspase-3 expression and reducing Bcl-2 levels. The in vivo transplantable tumor model (BALB/c mice injected with $4 \mathrm{~T} 1$ cells) showed that YLSPS inhibited tumor growth from day 7 to day 14 after tumor inoculation in YLSPS-treated rats $(150-600 \mathrm{mg} / \mathrm{kg}$ ). A reduction of serum MDA and increased SOD and GPX levels were observed in these animals, indicating an antioxidant action for YLSP. Apoptosis and reductions of VEGF and angiogenesis levels were observed in the tumor's samples treated with YLSP [74].

In another study, the dried tuber of Sparganium stoloniferum Buch. -Ham. (Sparganii Rhizoma), a traditional Chinese herbal medicine frequently used in the treatment of hyperacidity and gynecology disorders and in oncology (Pharmacopoeia of People's Republic of China, part I, 2015 edition), was investigated [44]. As the Sparganii rhizoma contains a substantial amount of polysaccharide, Wu et al. [44] isolated one from it, named SpaTA, by water extraction. The structure of SpaTA was described as a backbone consisting of 2 -Ograilsine- $\beta$-xylose $(4 \rightarrow 6)$ - $\alpha$-glucose $(1 \rightarrow 4)$ - $\beta$-mannose osamine [44]. An aluminium element combined with nitrogen on both grailsine and mannose osamine was identified in the repeating unit of SpaTA. The molecular weight was $5.250 \mathrm{kDa}$, and the monosaccharide composition consisted of xylose, glucose, and mannone osamine. ZR-75-1 (breast cancer cells ER $\alpha$ positive) was only at the concentration of $611.2 \mathrm{mg} / \mathrm{L}$ and inhibited cell proliferation after 72 and $96 \mathrm{~h}$ incubation [44]. The same concentrations, as well as intermediate ones $(152.8,305.6 \mathrm{mg} / \mathrm{L})$ of ZR-75-1, inhibited cell growth at 24 and $48 \mathrm{~h}$. SpaTA $(611.2 \mathrm{mg} / \mathrm{L})$ also increased the percentage of S-phase cells within $48 \mathrm{~h}$. Additionally, increased numbers of apoptotic cells and necrotic cells were observed between 72-96 $\mathrm{h}$ [44]. The results indicate that the incubation time is an important factor. At 305.6 and $611.2 \mathrm{mg} / \mathrm{L}$, SpaTA also induced ER $\alpha$ expression in ZR-75-1 cells at nuclear level, with concomitant increased levels of caspase 3, 8, 9, and PARP at $72 \mathrm{~h}$ (these results were not observed in cells knocked down for $E R \alpha$ ). The increased apoptotic proteins were confirmed to be ER $\alpha$-dependent, since in MDA-MB-231 cells (triple negative breast cancer cells), this effect was not observed [44].

Pyracantha fortuneana (Maxim.) Li (Huo-ji) is distributed mainly in the northwest of China, and its fruits are known to be enriched with Selenium (Se). The polysaccharides of P. fortuneana (PFPs) were previously shown to suppress inflammation and oxidative stress and to be hepatoprotective, antitumor, and antiviral [75-78]. Therefore, Yuan et al. [45] investigated whether polysaccharides extracted from Se-enriched P. fortuneana (Se-PFPs) presented anticancer activity in breast cancer cells [58]. The extract contained 93.7\% $(w / w)$ of carbohydrate, $2.1 \%$ of uronic acid, and $3.7 \mathrm{ug} / \mathrm{mL}$ of Se. The heteropolysaccharide was composed of xylose, arabinose, fucose, mannose, ribose, rhamnose, glucuronic acid, galacturonic acid, glucose, and galactose. In triple-negative breast cancer cells (MDAMB-231) Se-PFPs (up to $400 \mu \mathrm{g} / \mathrm{mL}$ ) inhibited cell growth in a concentration-dependent manner at 24 and $48 \mathrm{~h}$ following incubation. This effect was associated with cell cycle arrest at the G2 phase ( $400 \mathrm{ug} / \mathrm{mL}$ of Se-PFPs after $24 \mathrm{~h}$ ). The cell cycle arrest was suggested to be via inhibition of the cyclin B1/CDC2 pathway, enhancement of apoptotic proteins, such as caspase 3/9, p53, Bax, Puma, and Noxa, and decreased Bcl-2 expression. Treatment of nude mice bearing MDA-MB-231-derived xenograft tumors with Se-PFPs (100 and $400 \mathrm{mg} / \mathrm{kg}$, by oral route, for 30 days) significantly reduced tumor growth [45]. However, the in vivo mechanism of this polysaccharide was not investigated. Overall, Se-containing polysaccharides extracted from $P$. fortuneana presented an antitumor effect in breast cancer cells, probably through apoptosis induction, indicating its potential to treat triple-negative breast cancer [45].

\subsection{Fruits}

Five studies that explored polysaccharides isolated from fruits were found. Three studies used in vitro methodologies only, while two studies used in vitro and in vivo methodologies. 
Two studies evaluated the effects of polysaccharides isolated from the Lycium barbarum (Wolfberry, commercially known as Gojiberry). The chemical characterization of wolfberryderived polysaccharides (namely WFPs) revealed they were soluble in water and were non-starch protein-bounded acidic polysaccharides [46]. WFPs were mainly composed of D-galacturonic followed by D-galactose, L-arabinose, and D-glucose. The experiments designed with MCF-7 cells showed that WFPs $(25-200 \mu \mathrm{g} / \mathrm{mL}$ for 24 and $48 \mathrm{~h})$ presented antiproliferative effects and at the highest concentration $(100$ and $200 \mu \mathrm{g} / \mathrm{mL})$, induced cell cycle arrest at G0/G1. Moreover, flow cytometry analysis showed that WFPs exert a stimulatory effect on apoptosis and induce ROS production and DNA damage in a concentration-dependent manner. In conclusion, WFPs exert anticancer activities mediated by induction of apoptosis and ROS damage, which results in an antiproliferative effect [46].

Huang et al. [47] aimed to elucidate the transduction pathways responsible for mediating breast-cancer-suppressive effects of the polysaccharides isolated from Lycium barbarum (namely in the study as LBPs; MW: 30-100 kDa). By using MCF-7 cells, they found that $0.50 \mathrm{mg} / \mathrm{mL}$ of LBPs inhibits cell proliferation in a time-dependent manner and is antiangiogenic by inhibiting insulin-like growth factor (IGF)-1 protein and hypoxia-inducible factor-1 (HIF-1). The inhibition of IGF-1 was associated with the suppression of phosphatidylinositol 3-kinase (PI3K) activity, phosphorylated-PI3K (p-PI3K), and VEGF levels [47].

The polysaccharides from Hallabong peels were studied by Park et al. [48]. Hallabong is a type of orange from the Citrus sphaerocarpa found mainly in South Korea. Four polysaccharides were extracted from the peels, namely HB-I (MW: 64 and $60 \mathrm{kDa}$ ), HB-II (MW: 25kDa), HB-III (MW: 10 and $5.3 \mathrm{kDa}$ ), and HB-IV (MW: 4kDa). In MDA-MB-231 cells, only the highest tested concentration $(100 \mu \mathrm{g} / \mathrm{mL})$ of HB-II inhibited cell proliferation. No differences were found in angiogenesis markers following HB-II incubation. However, a reduction of MMP-9 expression was observed after HB-II treatment $(25 \mu \mathrm{g} / \mathrm{mL})$, suggesting its potential antimetastatic effect. Nonetheless, the results are preliminary, and additional investigations should be performed to further evaluate this effect [48].

Delphi and Sepehri [49] studied a pectic acid polysaccharide isolated from an apple. This polysaccharide has been demonstrated to have important effects on cancer pathways. The authors showed that an apple pectic acid polysaccharide (0.1-1\%) inhibited cell growth, induced apoptosis and decreased cell attachment, fragmented chromatin, and membrane blebbing. It also blocked the sub-G1 phase in 4T1 cancer cells. In a complementary way, by using female BALB/c mice, they demonstrated that daily supplementation with $1 \%$ of pectic acid polysaccharide for 3 weeks inhibited tumor growth and metastasis via over-expression of p53 and a high rate of apoptosis in tumor tissue [49].

Adami et al. [50] also studied a pectic polysaccharide. The polysaccharide fraction was obtained from the green sweet pepper (Capsicum annuum), and named CAP. The fraction was mainly composed of uronic acids, with minor amounts of rhamnose, arabinose, xylose, galactose, and glucose. CAP consisted of a highly methoxylated homogalacturonan with a type I arabinogalactan anchored to rhamnogalacturonan. CAP $(100 \mathrm{mg} / \mathrm{kg}$, by oral route, for 21 days) reduced Ehrlich tumor growth in vivo, and at the concentration of $0.1 \mathrm{mg} / \mathrm{mL}$, it decreased the viability and colony formation of MCF-7 and MDA-MB-436 human mammary cells. These results were associated with reduced gene expression of VEGF in vivo and in vitro. The polysaccharide fraction also reduced vessel areas, promoted necrosis, and increased IL-6 in the tumor tissue [50].

\subsection{Fungus}

Four studies with polysaccharides isolated from fungus (not mushrooms) were found. Only one study included animal experiments. Two studies evaluated the polysaccharide $\beta$-D-glucan. Jafaar et al. [51], studied a $\beta$-1-3-D-glucan isolated from S. cerevisae and compared its effects in endocrine-sensitive MCF-7 versus endocrine-resistant LCC9 and LY2 breast cancer cell lines. The cells were exposed to different concentrations $\beta$-glucan $(1-400 \mu \mathrm{g} / \mathrm{mL})$ for 48 and $72 \mathrm{~h}$. The $\beta$-D-glucan inhibited cell proliferation and increased $\mathrm{Bax} / \mathrm{Bcl}-2$ ratio in a concentration-dependent manner. On the other hand, the inhibition 
of NRF1 did not appear to be dependent on the concentration. The authors also showed regulation of the breast cancer-relevant gene expression (RASSF1 in MCF-7 cells; IGFBP3, CTNNB1, and ER $\beta$ in LCC9 cells) with $\beta$-D-glucan at 10 and $50 \mu \mathrm{g} / \mathrm{mL}$, indicating that this compound represents an attractive option for inhibiting endocrine-resistant breast cancer cell proliferation [51].

Another study evaluated the effects of three fungal exocellular $\beta$-glucans. The $\beta$ glucans were obtained from Botryosphaeria rhodian MAMB-05 (two botryosphaerans; (1$3)(1-6)-\beta$-D-glucan; one produced from glucose, the other from fructose) and Lasiodiplodia theobromae MMPI (lasiodiplodan; (1-6)- $\beta$-D-glucan, produced from glucose) in MCF7 cells. Botryosphaeran from glucose exhibited a time- and concentration-dependent antiproliferative activity, with a half-maximal inhibitory concentration of $100 \mu \mathrm{g} / \mathrm{mL}$. Botryosphaeran from fructose presented the best antiproliferative response at $1500 \mu \mathrm{g} / \mathrm{mL}$. The results with lasiodiplodan were similar to botryosphaeran. All the $\beta$-glucans increased oxidative stress, apoptosis (through induction of p53 and Bax), and necrosis in MCF-7 cells. Interestingly, the apoptosis induced by $\beta$-glucans $(100 \mu \mathrm{g} / \mathrm{mL}$ for $48 \mathrm{~h})$ was found to be mediated by AMP-activated protein-kinase and forkhead transcription factor FOXO3a [52].

Wang et al. [53], studied an exopolysaccharide (named EPS) isolated from the fermentation liquor of Trichoderma pseudokoningii fungus. The incubation of MCF-7 cells with EPS at $0.10,0.25,0.50,0.75$, and $1.0 \mathrm{mg} / \mathrm{mL}$ for 24,48 , and $72 \mathrm{~h}$ decreased cell viability and increased LDH release in a concentration-dependent manner. Apoptosis induction through activation of caspase-3, caspase- 8 , and caspase- 9 and increased Bax/Bcl-2 ratio was described at $0.25,0.50$, and $1 \mathrm{mg} / \mathrm{mL}$. Furthermore, EPS promoted the release of cytochrome $\mathrm{c}$ into the cytoplasm and disruption of mitochondrial membrane potential. Thus, EPS induced the apoptosis of MCF-7 cells through an intrinsic mitochondrial apoptotic pathway and may therefore be considered an effective adjuvant agent against human breast cancer [53].

The only study that included animal experimentation was conducted by Xie et al. [54]. In very well-designed study, they studied a non-ionic, non-immunogenic polysaccharide produced by Aureobasidium pullulan, a spermine modified pullulan (PS, MW: 90.000). Focusing on the immunomodulatory function, they first demonstrated in vitro, using Raw 264.7 cells, that the pullulan polysaccharide upregulated the expression of toll-like receptor $1 / 3$ and 4 and promoted the phosphorylation of AKT, ERK, and JNK and the activation of the NF- $\mathrm{KB}$ pathway. They suggested that this response may be related to M1 polarization. By using a heterotopic breast cancer model (4T1 in vivo cell inoculation), the polysaccharide ( $2.4 \mathrm{mg} / \mathrm{kg}$, by the subcutaneous route, 11 times for 21 days) induced an effective antitumor effect through reprogramming of M2 to M1 in the tumor microenvironment. Increased $\mathrm{CD}^{+}$and $\mathrm{CD}^{+} \mathrm{T}$ cells and decreased expression of CD31 in the tumor mass were also observed [54].

\subsection{Mushrooms}

Gan et al. [55] designed a study to show the antiproliferative and apoptotic activities of an acidic polysaccharide fraction from Pholiota dinghuensis Bi mycelium, named PDP-3 (MW: $353 \mathrm{kDa}$ ), using MDA-MB-231 and MCF-7 cells. PDP-3 contained high contents of uronic acid, protein, and sulphur radical. The sugar composition of PDP-3 contains glucose, mannose, xylose, galactose, fructose, and rhamnose. PDP-3 prevented cell growth $(\mathrm{EC} 50=38.35 \mu \mathrm{g} / \mathrm{mL})$ in both MDA-MB-231 and MCF-7 cells in a concentration-dependent manner. Proliferation inhibition in MCF-7 cells (PDP-3, 13-52 $\mu \mathrm{g} / \mathrm{mL}$ ) was associated with diminished proliferating cell nuclear antigen (PCNA), cyclin D1, and cyclin-dependent kinase 4 (CDK4) expression. Furthermore, PDP-3 also induced apoptosis through the stimulation of p21, caspase 3, and Bax expression and downregulation of Bcl-2 and caspase9. Downregulation of TNF receptor-associated factor 2 (TRAF2) and up-regulation of p38, p53, and apoptosis signal-regulating kinase 1 (ASK1) phosphorylation were also described. In addition, PDP-3 decreased both the nuclear and cytoplasmic expression of $\mathrm{ER} \alpha$. In summary, PDP-3 inhibited tumor proliferation and induced apoptosis through 
the activation of p38/MAPK [55]. It is important to point out that PDP-3 is also able to downregulate ER in MCF-7 cells, contributing to its antitumor effect.

Thus, Luo et al. [56] evaluated the polysaccharides (namely as SP1) present in Hauier fruiting bodies in breast cancer cells. The total carbohydrate content of SP1 was $\sim 94 \%$, and no uronic acid or proteins were detected. The monosaccharide composition included galactose, arabinose, and glucose, and the molecular weight was $56 \mathrm{kDa}$. SP1 inhibited MCF-7, MDA-MB-231, and MDA-MB-435 cell proliferation in concentrations higher than $400 \mu \mathrm{g} / \mathrm{mL}$. In MCF-7 cells, SP-1 (at 100, 200, and $400 \mu \mathrm{g} / \mathrm{mL}$ ) induced apoptosis through increasing Bax expression and decreasing MTDH levels, which is frequently upregulated in various human tumor types, including breast cancer [56].

Cordyceps sp. a parasitic type of mushroom, is also a traditional Chinese medicine and known to contain large amounts of polysaccharides. Lin et al. [57] studied a newly isolated polysaccharide (named MHP-1) from Mortierella hepialid, the asexual structure of Cordyceps sinensis. In vitro, MHP-1 (0.1-1 $\mu \mathrm{M})$ decreased cell migration in MDA-MB-231, MCF-7, and MDA-MB-468 cells. In these cells, E-cadherin and zonula occludens-1 (ZO-1) expressions were increased, and vimentin and fibronectin levels were diminished. The transcription factor snail was also significantly downregulated. MHP-1 also inhibited the protein levels of slug, suppressed EMT breast cancer, and decreased MMP-9 secretion. Furthermore, TGF- $\beta$ signaling was inhibited and the sensitivity in topotecan (TPT)-resistant MCF-7 cells was restored. By using a xenograft model in nude mice (MDA-MB-231) $(60 \mathrm{mg} / \mathrm{kg}$, by the intravenous route, for 4 weeks), the authors showed MHP-1 treatment led to inhibition of breast cancer metastasis, followed by a decreased expression of TGF $\beta$ type I receptor kinase (ALK5) and vimentin and increased expression of E-cadherin by MHP-1 [57].

The other two studies evaluated lentinan (LTN), a $\beta-(1 \rightarrow 6)$ branched $\beta-(1 \rightarrow 3)$-glucan derived from the mushroom of Lentinus edodes. Xu, Zou, and $\mathrm{Xu}$. [52], studied LTN in $\mathrm{ER}^{+}$human breast cancer cell lines (MCF-7 and T47D) and triple-negative cell lines (MDAMB-231 and MDA-MB-468) [58]. Interestingly, only the proliferation of MCF-7 and T47D cells was inhibited by LTN (12.5-400 $\mu \mathrm{g} / \mathrm{mL})$. LTN targeted p53 and ER $\alpha$ to inhibit MCF-7 cell proliferation. Additionally, $1 \mathrm{mg} / \mathrm{kg}$ LTN decreased tumor growth in female athymic $\mathrm{BALB} / \mathrm{c}$ nude mice (inoculated with MCF-7 cells). In addition, apoptosis was observed in the tumor tissue; this was associated with increased p53 and caspase 3 and reduction of Bcl-2 expression. The suppression of cell proliferation and apoptosis is probably through multiple pathways such as p53-dependent, caspase, PI3K/AKT/mTOR, NF-kB-, ERK-, and $\mathrm{ER} \alpha$ pathways. Overall, this study provided new insights to treat $\mathrm{ER}^{+}$breast cancers using LTN [58].

Similarly, Li Z et al. [59] investigated in more detail the anticancer mechanism of LTN in MCF-7. An aqueous LTN extract (ALNT) was prepared from Lentinus edodes. The sugar content was $\sim 96 \%$ and the molecular weight was $630 \mathrm{kDa}$. ALNT $(250-1000 \mu \mathrm{g} / \mathrm{mL})$ modulated autophagy by increasing LC3 conversion and decreasing p62. Apoptosis was also observed and was related to increased caspase 7 and Bax expression in MCF-7 cells. An antitumor effect of ALNT (5-20 mg/ $\mathrm{kg}$, i.v. for 3 weeks) was also observed in a xenograft in vivo model using MCF-7 cells. ALNT inhibited tumor growth, apoptosis, and autophagy. An increased expression of caspase 7 and Bax was observed in vivo, in addition to cytochrome c release and LC3 conversion [59].

\section{Discussion}

Analysis of non-clinical breast cancer models revealed that the mechanisms of action of polysaccharides involve apoptosis, inhibition of cellular proliferation, and angiogenesis, in addition to antimetastatic effects through multiple pathways. Clearly, fucoidan and $\beta$ glucans are the most well-studied polysaccharides with established antitumor mechanism (Figure 4). 


\section{Breast cancer}

\section{Fucoidan and $\beta$-glucans}

are the most well studied polysaccharides with established antitumor mechanism

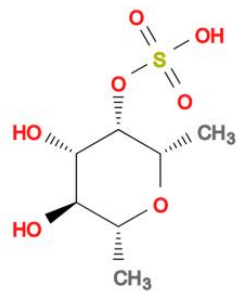

Fucoidan (representative structure)

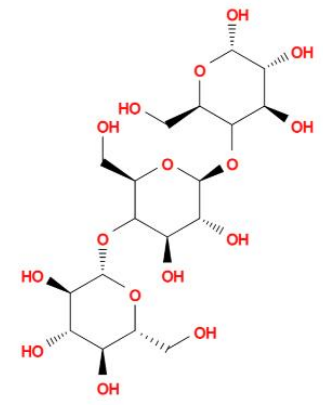

$\beta$-glucan

(representative structure)

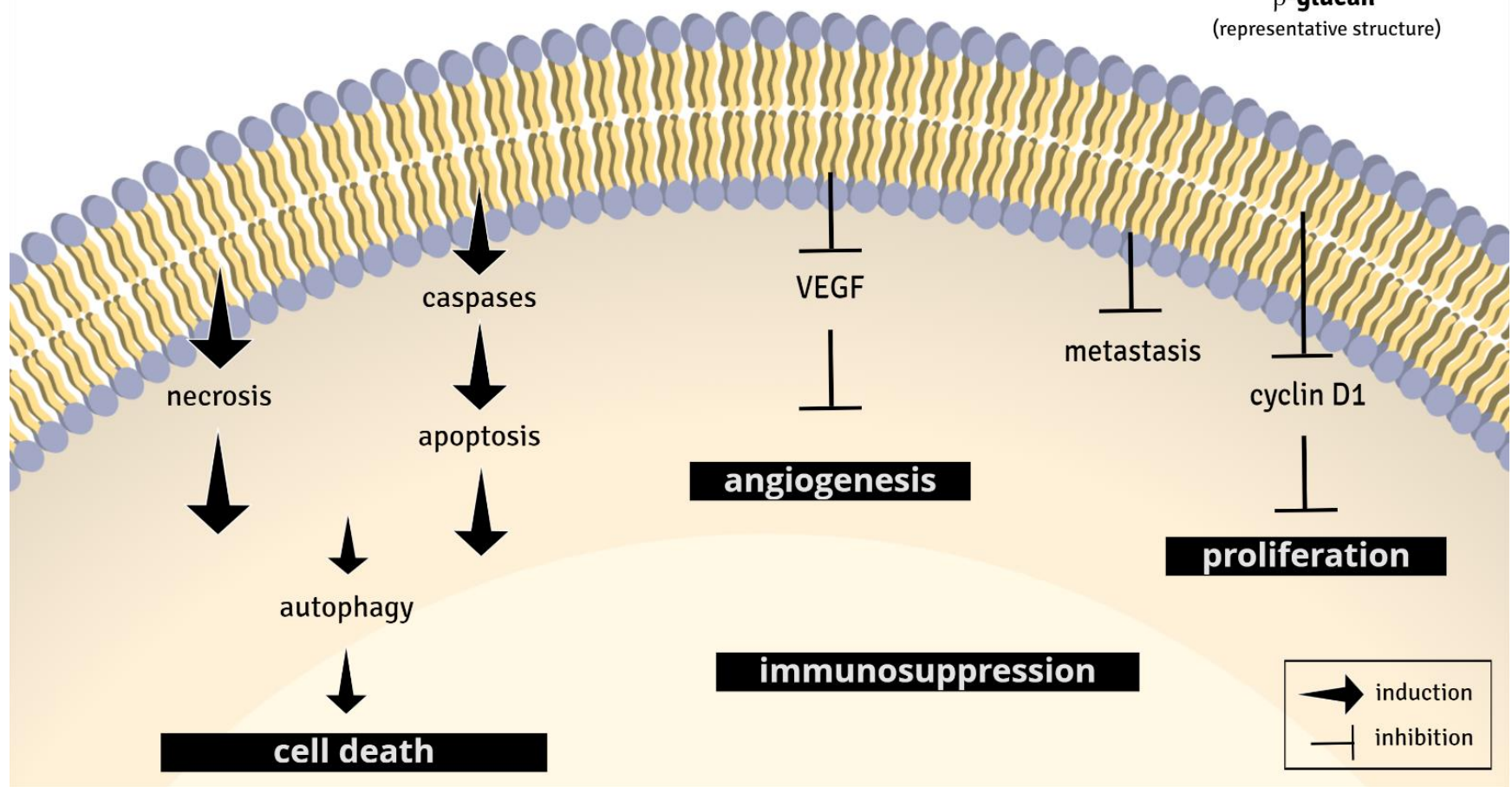

Figure 4. Representative image of the main anti-tumor pharmacological mechanism of fucoidan and $\beta$-glucans. Fucoidan and $\beta$-glucans can induce apoptosis, cell death, and immune suppression and inhibit angiogenesis, metastasis, and cell proliferation, through different signaling pathways (described in detail in Table 1).

Fucoidan, also called fucan or fucoidan, is a sulfated polysaccharide mainly found in different species of brown algae, as part of their cell walls [79]. Among the brown algae species containing fucoidan, Fucus vesiculosus was the most investigated. The studies indicate that the structures and compositions of fucoidan vary among brown algae species; however, they generally contain a black bone of sulfated fucan, along with small quantities of D-galactose, D-mannose, D-xylose, and uronic acid. Fucoidan has been extensively studied since its first isolation in 1913 and has been consumed as a dietary fiber in many Asian countries $[24,80]$. Fucoidan presents a variety of biological activities, including antithrombotic, antiviral, antioxidant, anti-inflammatory, and immunomodulatory actions. Its anticancer effects have gained considerable attention due to its antitumor properties in B- and T-cell lymphoma, leukemia, fibroblastic and uterine sarcoma, osteosarcoma, hepatocellular and endometrium carcinoma, melanoma, and lung, colorectal, bladder, stomach, pancreatic, ovarian, and prostate cancer [80]. In breast cancer models, fucoidan induced apoptosis and inhibited cell proliferation through interaction with several signaling pathways [35]. Importantly, fucoidan reduced tumor growth and weight and metastasis [26,60]. Some inconsistencies were found between the studies [26,27], concerning the dose used to investigate the anti-tumor effect of fucoidan. For instance, the dose used by Hsu et al. [31], was higher compared to the study conducted by Chen et al. [27]. 
This particularity also reflects in the results found by Zhang et al. [32] that studied a LMWF from the algae Laminaria japonica [32]. The molecular weight is generally classified as low $(\leq 10 \mathrm{kDa})$, medium $(10-10.000 \mathrm{kDa})$, and high $(\geq 10.000 \mathrm{kDa})$ [81], and it is known that LMWF is more soluble in water; thus, a higher bioavailability in vivo was observed [32]. Therefore, the differences may occur because different types of extraction (chemical, physical, or enzymatic treatment) and purification methods to obtain fucoidan can result in a distinct structure and molecular weight, and consequently, different pharmacological effects.

The anticancer effect of fucoidan is also well consolidated in animal models. Importantly, one study showed the potential immunomodulatory effect of fucoidan on breast cancer cells through the de PDL-1 axis, and all the effects were observed in triple-negative breast cancer cells (MDA-MB-231 and 4T1 cells) or estrogen-sensitive cells (MCF-7).

Both fucoidan from Fucus vesiculosus and Undaria pinnatifida are approved in the USA by Food and Drug Administration (FDA) in the Generally Recognized As Safe (GRAS) category as food ingredients, based on the lack of toxicity in vivo and in a clinical trial $[82,83]$. Furthermore, several studies explored the anticancer potential effect of fucoidan in different types of cancer as an adjuvant treatment and its ability to improve patient's quality of life [84]. However, although it has been well explored, no clinical studies have been found with fucoidan in regarding to breast cancer.

$\beta$-glucans have also been extensively studied and have attracted considerable attention worldwide. Glucans refer to a diverse class of glucose polymers that can be short or long, branched or unbranched, $\alpha$ or $\beta$ isomers, and soluble or particulate. Particularly, $\beta-1,3-$ D-glucans can be found in yeast (typically Saccharomyces cerevisiae), mushrooms, bacteria, plant cell walls, and seaweed. $\beta-1,3$-glucan has important interactions with the human body, mainly with the immune system, which gives this type of polysaccharide a wide range of biological effects [85]. $\beta$-glucans can exhibit direct and indirect antiproliferative effects against breast cancer cells, and the findings provide valuable information about the possible mechanistic insights about its antiproliferative role [83]. Among $\beta$-glucans, the best-investigated polysaccharide was Lentinan. Lentinan is described to have an anticancer effect on gastric, hepatic, ovarian, and lung cancer. Lentinan was studied in human breast

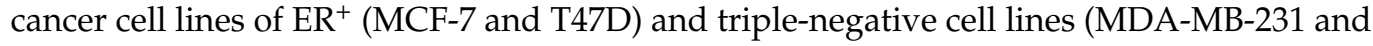
MDA-MB-468) and inhibited only MCF-7 and T47D cell proliferation.

Of importance, $\beta$-glucans are already employed as adjuvant therapy in cancer treatment to improve the immune system response [83]. Several clinical trials already reported increased quality of life and an immune stimulatory effect of $\beta$-glucans in patients with breast cancer under chemotherapy. Increased blood cells count, serum levels of IL-4 and IL-12 and activation of peripheral blood monocytes were described [52,86-88]. However, none of the studies selected in our systematic review evaluated the immunostimulatory effect of $\beta$-glucans per se in breast cancer models. $\beta$-glucans from yeast are also approved in the USA by FDA as GRAS [82,89], but no clinical trials were performed yet on breast cancer patients.

Other polysaccharides described here may also be candidate agents for more detailed studies and perhaps clinical trials. The Levan polysaccharide derived from bacteria and the polysaccharides from red and brown algae (Laurencia papillosa and Undaria pinnatifida), as well as some pectins from fruits, showed an interesting antitumor response [38,39]. At least two studies documented the antitumor effect. However, in vivo experiments, well-structured in relation to dose and treatment time, and those that aim to assess toxicity with well-designed methodologies and correct statistical tests should be performed.

For instance, Delphi and Sepehri [49] and Adami et al. [50] arranged their studies including in vivo and in vitro methodologies to study pectic polysaccharide isolates from fruits. This strategy brings up advanced and robust information to better comprehend the polysaccharide activity and mechanism of action [49,50].

Certainly, other polysaccharides included in this systematic review also attracted attention for their initial results. However, those studies are still in the beginning, and more 
detailed investigations need to be conducted to engender a comparative discussion. Only a few studies attempted to investigate the immunomodulatory activity of polysaccharides. None of the articles investigate the HER2 or progesterone receptor involvement with the polysaccharide antitumor effect, and only three evaluate the estrogen receptor. Particularly, these experiments should be included when evaluating the anticancer effect of molecules to provide knowledge of which type of breast cancer the molecule could be used to treat. Importantly, most of the studies only employed in vitro experiments. The inclusion of in vivo animal models is strongly encouraged. Xenograft models, using human breast cancer cells, are closer to human conditions and could provide more information on the effect of these molecules as well as the potential toxicity. Furthermore, although studies make little or no inference, the relation between the structural characteristics and pharmacological activity of the polysaccharide must be considered to facilitate subsequent studies.

Finally, we discussed here only articles with high-quality methodology and low risk of bias. Additional studies are required to elucidate the polysaccharides' effects, mechanism of action, and toxicity before the initiation of translational research and clinical studies. Our systematic review also provides new insights to improve the knowledge of which polysaccharides could be further investigated for the treatment of breast cancer.

\section{Conclusions}

We performed a systematic review of non-clinical studies reporting on the antitumor effect of naturally occurring polysaccharides and their mechanism of action. A thorough search was carried out to include only studies with high quality of evidence and without risk of bias. Parallel considerations of the polysaccharides that were better explored and with a well-defined mechanism of action in non-clinical trials have enabled an exploration of the extent to which one may have the potential for translational research and clinical studies on breast tumor. There appears to be strong evidence in support of some polysaccharides' ability as new intervention strategies in the treatment of breast cancer. However, there is still a deficiency regarding data concerning structural polysaccharides' characteristics, bioavailability, and pharmacokinetics. Fucoidan and $\beta$-glucan polysaccharides appear to be the most well-defined polysaccharides concerning their mechanism of action in non-clinical models. Translational research into clinics as monotherapy still needs to be strategically evaluated before it becomes a reality in the field of cancer control.

Author Contributions: The overall information on search strategy and study selection was compiled by C.R.C., N.M.T.d.O. and L.M.C. Data extraction was performed by C.R.C., N.M.T.d.O., L.M.C., K.S.d.S. and D.M.-F. Assessment of risk of bias was performed by C.R.C., N.M.T.d.O., L.M.C., V.F.R., S.H.d.S.S. and D.M.-F. Discrepancies in any phases of the systematic review were resolved by the senior author D.M.-F. The study was conceived and designed by D.M.-F. and E.S.F., who critically revised the manuscript. All authors have read and agreed to the published version of the manuscript.

Funding: This work was supported by the Conselho Nacional de Desenvolvimento Científico e Tecnológico (CNPq; Brazil; grant numbers: 305676/2019-9 and 408053/2018-6) and the Instituto de Pesquisa Pelé Pequeno Príncipe (Brazil). C.R.C. is a post-doc student and N.M.T.d.O. and S.H.S.S. are PhD student, receiving a grant from the Coordenação de Aperfeiçoamento de Pessoal de Nível Superior (CAPES; finance code 001; Brazil). K.S.S. is an MSc student receiving a grant from the Instituto de Pesquisa Pelé Pequeno Príncipe.

Institutional Review Board Statement: Not applicable.

Informed Consent Statement: Not applicable.

Data Availability Statement: Not applicable.

Acknowledgments: Not applicable.

Conflicts of Interest: The authors have no relevant interests to declare. 


\section{References}

1. Bodai, B. Breast Cancer Survivorship: A Comprehensive Review of Long-Term Medical Issues and Lifestyle Recommendations. Perm. J. 2019, 19, 48-79. [CrossRef] [PubMed]

2. Stewart, B.W.; Wild, C.P. World Cancer Report 2014; IARC: Lyon, France, 2014.

3. World Health Organization. Life Expectancy at Birth (Years); World Health Organization: Geneva, Switzerland, 2019.

4. Torre, L.A.; Siegel, R.L.; Ward, E.M.; Jemal, A. Global Cancer Incidence and Mortality Rates and Trends-An Update. Cancer Epidemiol. Biomark. Prev. 2015, 25, 16-27. [CrossRef] [PubMed]

5. Ginsburg, O.; Bray, F.; Coleman, M.P.; Vanderpuye, V.; Eniu, A.; Kotha, S.R.; Sarker, M.; Huong, T.T.; Allemani, C.; Dvaladze, A.; et al. The global burden of women's cancers: A grand challenge in global health. Lancet 2017, 389, 847-860. [CrossRef]

6. Allemani, C.; Weir, H.K.; Carreira, H.; Harewood, R.; Spika, D.; Wang, X.-S.; Bannon, F.; Ahn, J.V.; Johnson, C.J.; Bonaventure, A.; et al. Global surveillance of cancer survival 1995-2009: Analysis of individual data for 25,676,887 patients from 279 populationbased registries in 67 countries (CONCORD-2). Lancet 2015, 385, 977-1010. [CrossRef]

7. Waks, A.G.; Winer, E.P. Breast Cancer Treatment: A Review. JAMA 2019, 321, 288-300. [CrossRef]

8. Harbeck, N.; Gnant, M. Breast cancer. Lancet 2017, 389, 1134-1150. [CrossRef]

9. Giordano, S.H.; Temin, S.; Kirshner, J.J.; Chandarlapaty, S.; Crews, J.R.; Davidson, N.E.; Esteva, F.J.; Gonzalez-Angulo, A.M.; Krop, I.; Levinson, J.; et al. Systemic Therapy for Patients with Advanced Human Epidermal Growth Factor Receptor 2-Positive Breast Cancer: American Society of Clinical Oncology Clinical Practice Guideline. J. Clin. Oncol. 2014, 32, 2078-2099. [CrossRef]

10. Poortmans, P. Postmastectomy radiation in breast cancer with one to three involved lymph nodes: Ending the debate. Lancet 2014, 383, 2104-2106. [CrossRef]

11. Wang, X.; Zhang, H.; Chen, X. Drug resistance and combating drug resistance in cancer. Cancer Drug Resist. 2019, 2, 141-160. [CrossRef]

12. Mitra, S.; Dash, R. Natural Products for the Management and Prevention of Breast Cancer. Evid.-Based Complement. Altern. Med. 2018, 2018, 1-23. [CrossRef]

13. Meng, X.; Liang, H.; Luo, L. Antitumor polysaccharides from mushrooms: A review on the structural characteristics, antitumor mechanisms and immunomodulating activities. Carbohydr. Res. 2016, 424, 30-41. [CrossRef]

14. C.Ooi, V.E. Immunomodulation and Anti-Cancer Activity of Polysaccharide-Protein Complexes. Curr. Med. Chem. 2000, 7, 715-729. [CrossRef] [PubMed]

15. Bao, X.; Duan, J.; Fang, X.; Fang, J. Chemical modifications of the $(1 \rightarrow 3)-\alpha$-d-glucan from spores of Ganoderma lucidum and investigation of their physicochemical properties and immunological activity. Carbohydr. Res. 2001, 336, 127-140. [CrossRef]

16. Smith, J.E.; Rowan, N.J.; Sullivan, R. Medicinal mushrooms: A rapidly developing area of biotechnology for cancer therapy and other bioactivities. Biotechnol. Lett. 2002, 24, 1839-1845. [CrossRef]

17. Tao, Y.; Zhang, L.; Cheung, P.C. Physicochemical properties and antitumor activities of water-soluble native and sulfated hyperbranched mushroom polysaccharides. Carbohydr. Res. 2006, 341, 2261-2269. [CrossRef]

18. Zhang, M.; Cui, S.; Cheung, P.; Wang, Q. Antitumor polysaccharides from mushrooms: A review on their isolation process, structural characteristics and antitumor activity. Trends Food Sci. Technol. 2007, 18, 4-19. [CrossRef]

19. Fan, Y.; Lin, M.; Luo, A.; Chun, Z.; Luo, A. Characterization and Antitumor Activity of a Polysaccharide from Sarcodia ceylonensis. Molecules 2014, 19, 10863-10876. [CrossRef] [PubMed]

20. Alwarsamy, M.; Gooneratne, R.; Ravichandran, R. Effect of fucoidan from Turbinaria conoides on human lung adenocarcinoma epithelial (A549) cells. Carbohydr. Polym. 2016, 152, 207-213. [CrossRef]

21. Shamseer, L.; Moher, D.; Clarke, M.; Ghersi, D.; Liberati, A.; Petticrew, M.; Shekelle, P.; Stewart, L.A. Preferred reporting items for systematic review and meta-analysis protocols (PRISMA-P) 2015: Elaboration and explanation. Br. Med. J. 2015, 349 , g7647. [CrossRef] [PubMed]

22. Hooijmans, C.R.; Rovers, M.M.; De Vries, R.B.M.; Leenaars, M.; Ritskes-Hoitinga, M.; Langendam, M.W. SYRCLE's risk of bias tool for animal studies. BMC Med. Res. Methodol. 2014, 14, 43. [CrossRef]

23. Lee, K.-S.; Shin, J.-S.; Nam, K.-S. Starfish polysaccharides downregulate metastatic activity through the MAPK signaling pathway in MCF-7 human breast cancer cells. Mol. Biol. Rep. 2013, 40, 5959-5966. [CrossRef] [PubMed]

24. Xue, M.; Ge, Y.; Zhang, J.; Wang, Q.; Hou, L.; Liu, Y.; Sun, L.; Li, Q. Anticancer Properties and Mechanisms of Fucoidan on Mouse Breast Cancer In Vitro and In Vivo. PLoS ONE 2012, 7, e43483. [CrossRef]

25. Xue, M.; Ge, Y.; Zhang, J.; Liu, Y.; Wang, Q.; Hou, L.; Zheng, Z. Fucoidan Inhibited 4T1 Mouse Breast Cancer Cell Growth In Vivo and In Vitro Via Downregulation of Wnt/ $\beta$-Catenin Signaling. Nutr. Cancer 2013, 65, 460-468. [CrossRef] [PubMed]

26. Hsu, H.-Y.; Lin, T.-Y.; Hwang, P.-A.; Tseng, L.-M.; Chen, R.-H.; Tsao, S.-M.; Hsu, J. Fucoidan induces changes in the epithelial to mesenchymal transition and decreases metastasis by enhancing ubiquitin-dependent TGF receptor degradation in breast cancer. Carcinogenesis 2012, 34, 874-884. [CrossRef] [PubMed]

27. Chen, S.; Zhao, Y.; Zhang, Y.; Zhang, D. Fucoidan Induces Cancer Cell Apoptosis by Modulating the Endoplasmic Reticulum Stress Cascades. PLoS ONE 2014, 9, e108157. [CrossRef]

28. Xue, M.; Ji, X.; Xue, C.; Liang, H.; Ge, Y.; He, X.; Zhang, L.; Bian, K.; Zhang, L. Caspase-dependent and caspase-independent induction of apoptosis in breast cancer by fucoidan via the PI3K/AKT/GSK3 $\beta$ pathway in vivo and in vitro. Biomed. Pharmacother. 2017, 94, 898-908. [CrossRef] 
29. Xue, M.; Liang, H.; Tang, Q.; Xue, C.; He, X.; Zhang, L.; Zhang, Z.; Liang, Z.; Bian, K.; Zhang, L.; et al. The Protective and Immunomodulatory Effects of Fucoidan Against 7,12-Dimethyl benz[a]anthracene-Induced Experimental Mammary Carcinogenesis Through the PD1/PDL1 Signaling Pathway in Rats. Nutr. Cancer 2017, 69, 1-11. [CrossRef]

30. He, X.; Xue, M.; Jiang, S.; Li, W.; Yu, J.; Xiang, S. Fucoidan Promotes Apoptosis and Inhibits EMT of Breast Cancer Cells. Biol. Pharm. Bull. 2019, 42, 442-447. [CrossRef]

31. Hsu, W.-J.; Lin, M.-H.; Kuo, T.-C.; Chou, C.-M.; Mi, F.-L.; Cheng, C.-H.; Lin, C.-W. Fucoidan from Laminaria japonica exerts antitumor effects on angiogenesis and micrometastasis in triple-negative breast cancer cells. Int. J. Biol. Macromol. 2020, 149, 600-608. [CrossRef]

32. Zhang, Z.; Teruya, K.; Eto, H.; Shirahata, S. Fucoidan Extract Induces Apoptosis in MCF-7 Cells via a Mechanism Involving the ROS-Dependent JNK Activation and Mitochondria-Mediated Pathways. PLoS ONE 2011, 6, e27441. [CrossRef]

33. Zhang, Z.; Teruya, K.; Yoshida, T.; Eto, H.; Shirahata, S. Fucoidan Extract Enhances the Anti-Cancer Activity of Chemotherapeutic Agents in MDA-MB-231 and MCF-7 Breast Cancer Cells. Mar. Drugs 2013, 11, 81-98. [CrossRef]

34. Wu, S.-Y.; Yan, M.-D.; Wu, A.T.; Yuan, K.S.-P.; Liu, S.H. Brown Seaweed Fucoidan Inhibits Cancer Progression by Dual Regulation of mir-29c/ADAM12 and miR-17-5p/PTEN Axes in Human Breast Cancer Cells. J. Cancer 2016, 7, 2408-2419. [CrossRef]

35. Yamasaki, Y.; Yamasaki, M.; Tachibana, H.; Yamada, K. Important Role of $\beta 1$-Integrin in Fucoidan-Induced Apoptosis via Caspase-8 Activation. Biosci. Biotechnol. Biochem. 2012, 76, 1163-1168. [CrossRef]

36. Murad, H.; Ghannam, A.; Al-Ktaifani, M.; Abbas, A.; Hawat, M. Algal sulfated carrageenan inhibits proliferation of MDA-MB-231 cells via apoptosis regulatory genes. Mol. Med. Rep. 2014, 11, 2153-2158. [CrossRef] [PubMed]

37. Ghannam, A.; Murad, H.; Jazzara, M.; Odeh, A.; Allaf, A.W. Isolation, Structural characterization, and antiproliferative activity of phycocolloids from the red seaweed Laurencia papillosa on MCF-7 human breast cancer cells. Int. J. Biol. Macromol. 2018, 108, 916-926. [CrossRef]

38. Han, Y.; Wu, J.; Liu, T.; Hu, Y.; Zheng, Q.; Wang, B.; Lin, H.; Li, X. Separation, characterization and anticancer activities of a sulfated polysaccharide from Undaria pinnatifida. Int. J. Biol. Macromol. 2016, 83, 42-49. [CrossRef] [PubMed]

39. Wu, J.; Li, H.; Wang, X.; Zhang, X.; Liu, W.; Wang, Y.; Zhang, Y.; Pan, H.; Wang, Q.; Han, Y. Effect of polysaccharide from Undaria pinnatifida on proliferation, migration and apoptosis of breast cancer cell MCF7. Int. J. Biol. Macromol. 2019, 121, 734-742. [CrossRef] [PubMed]

40. Queiroz, E.A.; Fortes, Z.B.; da Cunha, M.A.; Sarilmiser, H.K.; Dekker, A.M.B.; Öner, E.T.; Dekker, R.F.; Khaper, N. Levan promotes antiproliferative and pro-apoptotic effects in MCF-7 breast cancer cells mediated by oxidative stress. Int. J. Biol. Macromol. 2017, 102, 565-570. [CrossRef] [PubMed]

41. Li, Z.; Sun, X.; Liu, X.; Sun, Z.; Li, J. Antitumor Effects of Ruyiping on Cell Growth and Metastasis in Breast Cancer. Cancer Biother. Radiopharm. 2019, 34, 297-305. [CrossRef]

42. Liu, C.; Li, H.; Wang, K.; Zhuang, J.; Chu, F.; Gao, C.; Liu, L.; Feng, F.; Zhou, C.; Zhang, W.; et al. Identifying the Antiproliferative Effect of Astragalus Polysaccharides on Breast Cancer: Coupling Network Pharmacology with Targetable Screening from the Cancer Genome Atlas. Front. Oncol. 2019, 9, 368. [CrossRef]

43. Qin, N.; Lu, S.; Chen, N.; Chen, C.; Xie, Q.; Wei, X.; Ye, F.; He, J.; Li, Y.; Chen, L.; et al. Yulangsan polysaccharide inhibits 4 T1 breast cancer cell proliferation and induces apoptosis in vitro and in vivo. Int. J. Biol. Macromol. 2019, 121, 971-980. [CrossRef]

44. Wu, Y.-Z.; Sun, J.; Wang, Y.-B. Selective estrogen receptor modulator: A novel polysaccharide from Sparganii Rhizoma induces apoptosis in breast cancer cells. Carbohydr. Polym. 2017, 163, 199-207. [CrossRef]

45. Yuan, C.; Wang, C.; Wang, J.; Kumar, V.; Anwar, F.; Xiao, F.; Mushtaq, G.; Liu, Y.; Kamal, M.A.; Yuan, D. Inhibition on the growth of human MDA-MB-231 breast cancer cells in vitro and tumor growth in a mouse xenograft model by Se-containing polysaccharides from Pyracantha fortuneana. Nutr. Res. 2016, 36, 1243-1254. [CrossRef]

46. He, N.; Yang, X.; Jiao, Y.; Tian, L.; Zhao, Y. Characterisation of antioxidant and antiproliferative acidic polysaccharides from Chinese wolfberry fruits. Food Chem. 2012, 133, 978-989. [CrossRef]

47. Huang, X.; Zhang, Q.-Y.; Jiang, Q.-Y.; Kang, X.-M.; Zhao, L. Polysaccharides derived from Lycium barbarum suppress IGF-1induced angiogenesis via PI3K/HIF-1 $\alpha$ /VEGF signalling pathways in MCF-7 cells. Food Chem. 2012, 131, 1479-1484. [CrossRef]

48. Park, J.Y.; Shin, M.S.; Kim, S.N.; Kim, H.Y.; Kim, K.H.; Shin, K.-S.; Kang, K.S. Polysaccharides from Korean Citrus hallabong peels inhibit angiogenesis and breast cancer cell migration. Int. J. Biol. Macromol. 2016, 85, 522-529. [CrossRef]

49. Delphi, L.; Sepehri, H. Apple pectin: A natural source for cancer suppression in $4 \mathrm{~T} 1$ breast cancer cells in vitro and express p53 in mouse bearing 4T1 cancer tumors, in vivo. Biomed. Pharmacother. 2016, 84, 637-644. [CrossRef] [PubMed]

50. Adami, E.R.; Corso, C.R.; de Oliveira, N.M.T.; Galindo, C.M.; Milani, L.; Stipp, M.C.; Nascimento, G.E.D.; Chequin, A.; da Silva, L.C.M.; de Andrade, S.F.; et al. Antineoplastic effect of pectic polysaccharides from green sweet pepper (Capsicum annuum) on mammary tumor cells in vivo and in vitro. Carbohydr. Polym. 2018, 201, 280-292. [CrossRef] [PubMed]

51. Jafaar, Z.M.; Litchfield, L.M.; Ivanova, M.M.; Radde, B.N.; Al-Rayyan, N.; Klinge, C.M. $\beta$-D-glucan inhibits endocrine-resistant breast cancer cell proliferation and alters gene expression. Int. J. Oncol. 2014, 44, 1365-1375. [CrossRef]

52. Queiroz, E.A.; Fortes, Z.B.; da Cunha, M.A.; Barbosa, A.M.; Khaper, N.; Dekker, R.F. Antiproliferative and pro-apoptotic effects of three fungal exocellular $\beta$-glucans in MCF-7 breast cancer cells is mediated by oxidative stress, AMP-activated protein kinase (AMPK) and the Forkhead transcription factor, FOXO3a. Int. J. Biochem. Cell Biol. 2015, 67, 14-24. [CrossRef] 
53. Wang, G.; Liu, C.; Liu, J.; Liu, B.; Li, P.; Qin, G.; Xu, Y.; Chen, K.; Liu, H.; Chen, K. Exopolysaccharide from Trichoderma pseudokoningii induces the apoptosis of MCF-7 cells through an intrinsic mitochondrial pathway. Carbohydr. Polym. 2016, 136, 1065-1073. [CrossRef]

54. Xie, L.; Yang, Y.; Meng, J.; Wen, T.; Liu, J.; Xu, H. Cationic polysaccharide spermine-pullulan drives tumor associated macrophage towards M1 phenotype to inhibit tumor progression. Int. J. Biol. Macromol. 2019, 123, 1012-1019. [CrossRef]

55. Gan, D.; Zeng, X.; Liu, R.H.; Ye, H. Potential mechanism of mycelium polysaccharide from Pholiota dinghuensis Bi in regulating the proliferation and apoptosis of human breast cancer MCF-7 cells through p38/MAPK pathway. J. Funct. Foods 2015, 12, 375-388. [CrossRef]

56. Luo, Z.; Hu, X.; Xiong, H.; Qiu, H.; Yuan, X.; Zhu, F.; Wang, Y.; Zou, Y. A polysaccharide from Huaier induced apoptosis in MCF-7 breast cancer cells via down-regulation of MTDH protein. Carbohydr. Polym. 2016, 151, 1027-1033. [CrossRef] [PubMed]

57. Lin, S.; Lyu, X.; Yu, J.; Sun, L.; Du, D.; Lai, Y.; Li, H.; Wang, Y.; Zhang, L.; Yin, H.; et al. MHP-1 inhibits cancer metastasis and restores topotecan sensitivity via regulating epithelial-mesenchymal transition and TGF- $\beta$ signaling in human breast cancer cells. Phytomedicine 2016, 23, 1053-1063. [CrossRef] [PubMed]

58. Xu, H.; Zou, S.; Xu, X. The $\beta$-glucan from Lentinus edodes suppresses cell proliferation and promotes apoptosis in estrogen receptor positive breast cancers. Oncotarget 2017, 8, 86693-86709. [CrossRef] [PubMed]

59. Li, W.; Wang, J.; Hu, H.; Li, Q.; Liu, Y.; Wang, K. Functional polysaccharide Lentinan suppresses human breast cancer growth via inducing autophagy and caspase-7-mediated apoptosis. J. Funct. Foods 2018, 45, 75-85. [CrossRef]

60. Pulaski, B.A.; Ostrand-Rosenberg, S. Mouse 4T1 Breast Tumor Model. Curr. Protoc. Immunol. 2000, 39, 20.2.1-20.2.16. [CrossRef]

61. Hammadi, M.; Oulidi, A.; Gackière, F.; Katsogiannou, M.; Slomianny, C.; Roudbaraki, M.; Dewailly, E.; Delcourt, P.; Lepage, G.; Lotteau, S.; et al. Modulation of ER stress and apoptosis by endoplasmic reticulum calcium leak via translocon during unfolded protein response: Involvement of GRP. FASEB J. 2012, 27, 1600-1609. [CrossRef]

62. Sriburi, R.; Jackowski, S.; Mori, K.; Brewer, J.W. XBP1 a link between the unfolded protein response, lipid biosynthesis, and biogenesis of the endoplasmic reticulum. J. Cell Biol. 2004, 167, 35-41. [CrossRef]

63. Kim, I.; Xu, W.; Reed, J.C. Cell death and endoplasmic reticulum stress: Disease relevance and therapeutic opportunities. Nat. Rev. Drug Discov. 2008, 7, 1013-1030. [CrossRef]

64. Murad, H.; Hawat, M.; Ekhtiar, A.; Aljapawe, A.; Abbas, A.; Darwish, H.; Sbenati, O.; Ghannam, A. Induction of G1-phase cell cycle arrest and apoptosis pathway in MDA-MB-231 human breast cancer cells by sulfated polysaccharide extracted from Laurencia papillosa. Cancer Cell Int. 2016, 16, 1-11. [CrossRef] [PubMed]

65. Toda, S.; Shirataki, Y. Inhibitory effects of Astragali Radix, a crude drug in Oriental medicines, on lipid peroxidation and protein oxidative modification by copper. J. Ethnopharmacol. 1999, 68, 331-333. [CrossRef]

66. Toda, S.; Yase, Y.; Shirataki, Y. Inhibitory effects of Astragali Radix, crude drug in oriental medicines on lipid peroxida-tion and protein oxidative modification of mouse brain homogenate by copper. Phyther. Res. 2000, 14, 294-296. [CrossRef]

67. Yin, G.; Jeney, G.; Racz, T.; Xu, P.; Jun, X.; Jeney, Z. Effect of two Chinese herbs (Astragalus radix and Scutellaria radix) on non-specific immune response of tilapia, Oreochromis niloticus. Aquaculture 2006, 253, 39-47. [CrossRef]

68. Lee, Y.S.; Han, O.K.; Park, C.W.; Yang, C.H.; Jeon, T.W.; Yoo, W.K.; Kim, S.H.; Kim, H.J. Pro-inflammatory cytokine gene expression and nitric oxide regulation of aqueous extracted Astragali radix in RAW 264.7 macrophage cells. J. Ethnopharmacol. 2005, 100, 289-294. [CrossRef]

69. Huang, G.-C.; Wu, L.-S.; Chen, L.-G.; Yang, L.-L.; Wang, C.-C. Immuno-enhancement effects of Huang Qi Liu Yi Tang in a murine model of cyclophosphamide-induced leucopenia. J. Ethnopharmacol. 2007, 109, 229-235. [CrossRef]

70. Cho, W.C.; Leung, K.N. In vitro and in vivo anti-tumor effects of Astragalus membranaceus. Cancer Lett. 2007, 252 , 43-54. [CrossRef]

71. Doan, V.M.; Chen, C.; Lin, X.; Nguyen, V.P.; Nong, Z.; Li, W.; Chen, Q.; Ming, J.; Xie, Q.; Huang, R. Yulangsan polysaccharide improves redox homeostasis and immune impairment in d-galactose-induced mimetic aging. Food Funct. 2015, 6, 1712-1718. [CrossRef]

72. Huang, J.; Nguyen, V.; Tang, X.; Wei, J.; Lin, X.; Lai, Z.; Doan, V.; Xie, Q.; Huang, R.; Van Nguyen, P.; et al. Protection from diclofenac-induced liver injury by Yulangsan polysaccharide in a mouse model. J. Ethnopharmacol. 2016, 193, 207-213. [CrossRef]

73. Zhang, X.; Liang, X.; Lin, X.; Zhang, S.; Huang, Z.; Chen, C.; Guo, Y.; Xuan, F.; Xu, X.; Huang, R. Mechanism of the Protective Effect of Yulangsan Flavonoid on Myocardial Ischemia/Reperfusion Injury in Rats. Cell. Physiol. Biochem. 2014, 34, 1050-1062. [CrossRef]

74. Lin, X.; Huang, Z.; Chen, X.; Rong, Y.; Zhang, S.; Jiao, Y.; Huang, Q.; Huang, R. Protective effect of Millettia pulchra polysaccharide on cognitive impairment induced by d-galactose in mice. Carbohydr. Polym. 2014, 101, 533-543. [CrossRef]

75. Zhou, X.; Wang, N.; Sun, P.; Bucheli, P.; Li, L.; Hou, Y.; Wang, J. Effects of Soluble Tea Polysaccharides on Hyperglycemia in Alloxan-Diabetic Mice. J. Agric. Food Chem. 2007, 55, 5523-5528. [CrossRef]

76. Monobe, M.; Ema, K.; Kato, F.; Maeda-Yamamoto, M. Immunostimulating Activity of a Crude Polysaccharide Derived from Green Tea (Camellia sinensis) Extract. J. Agric. Food Chem. 2008, 56, 1423-1427. [CrossRef] [PubMed]

77. Yuan, C.; Li, Z.; Yi, M.; Wang, X.; Peng, F.; Xiao, F.; Chen, T.; Wang, C.; Mushtaq, G.; Kamal, M. Effects of Polysaccharides from Selenium-enriched Pyracantha fortuneana on Mice Liver Injury. Med. Chem. 2015, 11, 780-788. [CrossRef] [PubMed]

78. Yuan, C.; Wang, C.; Bu, Y.; Xiang, T.; Huang, X.; Wang, Z.; Yi, F.; Ren, G.; Liu, G.; Song, F. Antioxidative and immunoprotective effects of Pyracantha fortuneana (Maxim.) Li polysaccharides in mice. Immunol. Lett. 2010, 133, 14-18. [CrossRef] [PubMed] 
79. Van Weelden, G.; Bobiński, M.; Okła, K.; Van Weelden, W.J.; Romano, A.; Pijnenborg, J.M.A. Fucoidan Structure and Activity in Relation to Anti-Cancer Mechanisms. Mar. Drugs 2019, 17, 32. [CrossRef]

80. Li, X.-M. Protective effect of Lycium barbarum polysaccharides on streptozotocin-induced oxidative stress in rats. Int. J. Biol. Macromol. 2007, 40, 461-465. [CrossRef]

81. Yamasaki-Miyamoto, Y.; Yamasaki, M.; Tachibana, H.; Yamada, K. Fucoidan Induces Apoptosis through Activation of Caspase-8 on Human Breast Cancer MCF-7 Cells. J. Agric. Food Chem. 2009, 57, 8677-8682. [CrossRef]

82. Citkowska, A.; Szekalska, M.; Winnicka, K. Possibilities of Fucoidan Utilization in the Development of Pharmaceutical Dosage Forms. Mar. Drugs 2019, 17, 458. [CrossRef]

83. Del Cornò, M.; Gessani, S.; Conti, L. Shaping the Innate Immune Response by Dietary Glucans: Any Role in the Control of Cancer? Cancers 2020, 12, 155. [CrossRef]

84. Hsu, H.; Hwang, P. Clinical applications of fucoidan in translational medicine for adjuvant cancer therapy. Clin. Transl. Med. 2019, 8, 15. [CrossRef] [PubMed]

85. Goodridge, H.S.; Wolf, A.J.; Underhill, D.M. $\beta$-glucan recognition by the innate immune system. Immunol. Rev. 2009, 230, 38-50. [CrossRef]

86. Demir, G.; Klein, H.; Mandel-Molinas, N.; Tuzuner, N. Beta glucan induces proliferation and activation of monocytes in peripheral blood of patients with advanced breast cancer. Int. Immunopharmacol. 2007, 7, 113-116. [CrossRef] [PubMed]

87. Ostadrahimi, A.; Esfahani, A.; Jafarabadi, M.A.; Ziaei, J.E.; Movassaghpourakbari, A.; Farrin, N. Effect of Beta Glucan on Quality of Life in Women with Breast Cancer Undergoing Chemotherapy: A Randomized Double-Blind Placebo-Controlled Clinical Trial. Adv. Pharm. Bull. 2014, 4, 471-477. [CrossRef]

88. Ostadrahimi, A.; Ziaei, J.E.; Esfahani, A.; Jafarabadi, M.A.; Movassaghpourakbari, A.; Farrin, N. Effect of Beta Glucan on White Blood Cell Counts and Serum Levels of IL-4 and IL-12 in Women with Breast Cancer Undergoing Chemotherapy: A Randomized Double-Blind Placebo-Controlled Clinical Trial. Asian Pac. J. Cancer Prev. 2014, 15, 5733-5739. [CrossRef]

89. Matsubara, K.; Xue, C.; Zhao, X.; Mori, M.; Sugawara, T.; Hirata, T. Effects of middle molecular weight fucoidans on in vitro and ex vivo angiogenesis of endothelial cells. Int. J. Mol. Med. 2005, 15, 695-699. [CrossRef] [PubMed] 